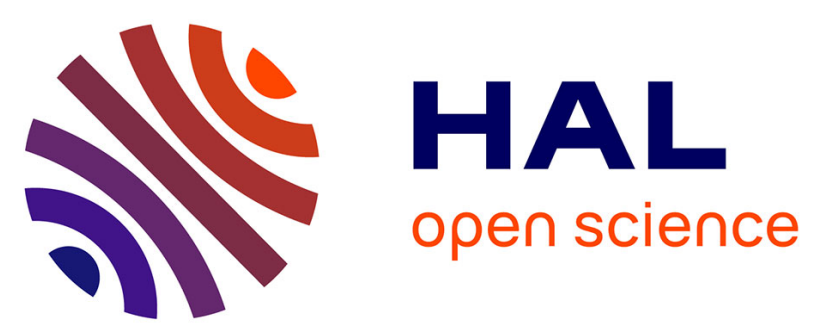

\title{
Occurrence of carbamazepine, diclofenac, and their related metabolites and transformation products in a French aquatic environment and preliminary risk assessment
}

Hiba Zind, Leslie Mondamert, Quentin Blancart Remaury, Alexis Cleon, Nathalie Karpel Vel Leitner, Jérôme Labanowski

\section{To cite this version:}

Hiba Zind, Leslie Mondamert, Quentin Blancart Remaury, Alexis Cleon, Nathalie Karpel Vel Leitner, et al.. Occurrence of carbamazepine, diclofenac, and their related metabolites and transformation products in a French aquatic environment and preliminary risk assessment. Water Research, 2021, 196, pp.117052. 10.1016/j.watres.2021.117052 . hal-03408879

\section{HAL Id: hal-03408879 \\ https://cnrs.hal.science/hal-03408879}

Submitted on 29 Oct 2021

HAL is a multi-disciplinary open access archive for the deposit and dissemination of scientific research documents, whether they are published or not. The documents may come from teaching and research institutions in France or abroad, or from public or private research centers.
L'archive ouverte pluridisciplinaire HAL, est destinée au dépôt et à la diffusion de documents scientifiques de niveau recherche, publiés ou non, émanant des établissements d'enseignement et de recherche français ou étrangers, des laboratoires publics ou privés. 

environment and preliminary risk assessment

8 Abstract

9 With questions emerging on the presence and risks associated with metabolites and

Hiba ZIND ${ }^{\mathrm{a}}$, Leslie MONDAMERT ${ }^{\mathrm{a}}$, Quentin BLANCART REMAURY ${ }^{\mathrm{a}}$, Alexis CLEON $^{\mathrm{a}}$, Nathalie KARPEL VEL LEITNER ${ }^{\mathrm{a}}$, Jérôme LABANOWSKI*a

anstitut de Chimie des Milieux et Matériaux de Poitiers, UMR CNRS 7285, University of Poitiers, France

*Corresponding author: jerome.labanowski@ univ-poitiers.fr transformation products (TPs) of organic contaminants in the aquatic environment, progress has been made in terms of monitoring and regulation of pesticide metabolites. However, less interest is shown for pharmaceutical residues, although their pseudo-persistence and adverse effects on non-target organisms are proven. This study provides original knowledge about the contamination of ten sites located along three French rivers (water, sediments, biofilms, clams) by pharmaceutical metabolites and TPs, as well as a preliminary environmental risk assessment. Studied compounds included carbamazepine with five metabolites and TPs, and diclofenac with three metabolites and TPs. Results show that metabolites and TPs are present in all studied compartments, with mean concentrations up to $0.52 \mu \mathrm{g} \mathrm{L}^{-1}$ in water, $229 \mathrm{ng} \mathrm{g}^{-1}$ in sediments, $2153 \mathrm{ng} \mathrm{g}^{-1}$ in biofilms, and $1149 \mathrm{ng} \mathrm{g}^{-1}$ in clams. QSAR estimations (OECD toolbox) were involved to predict the studied compounds ecotoxicities. QSAR models showed that diclofenac and its metabolites and TPs could be more toxic than carbamazepine and its metabolites and TPs to three aquatic species representing green algae, invertebrates, and fish. However, real ecotoxicological effects are still to be determined. The environmental risk assessment showed that hydroxydiclofenac, 2-[(2-chlorophenyl)-amino]-benzaldehyde and 
25 dibenzazepine could present a greater risk than other studied compounds for aquatic

26 organisms. In addition, the risk associated with a mixture of diclofenac and its related

27 metabolites and TPs has been found to be greater than that of the compounds considered

28 individually.

29 Keywords

30 Pharmaceuticals, metabolites and transformation products, ecotoxicity, risk assessment, rivers

\section{Highlights}

32
- Pharmaceutical degradation products are found in several aquatic compartments.

- Levels of degradation products are comparable with those of their parent compounds.

- By-products have similar or greater risk than pharmaceuticals in water and sediment.

- Some mixtures have a greater risk than pharmaceuticals considered individually.

\section{Introduction}

Pharmaceuticals enter into rivers mainly through wastewater discharge (wastewater treatment plants - WWTPs or septic tanks) and, to a lesser extent, from livestock (Daughton \& Ternes, 1999; Fent et al., 2006). These compounds are biologically active and are selected for their specific actions on the human or animal organism. Therefore, an exposure outside the medical or veterinary setting may lead to unwanted effects (toxic or disruptive effects) on living organisms. Many studies have already reported developmental disorders in frog tadpoles (Foster et al., 2010), fish feminization (Petrovic et al., 2002), changes in diversity and abundance of microbial communities (Liebig et al., 2010), etc. related to the exposure to pharmaceutical residues (at concentrations ranging from $n g \mathrm{~L}^{-1}$ to $\mu \mathrm{g} \mathrm{L}^{-1}$ ) via the aquatic 
47 environment. In the long term, all these effects could have major consequences on

48 biodiversity and water use (bathing, drinking water resources) in relation to human health:

49 e.g. exposure to endocrine disruptors or resistant pathogenic microorganisms (Amarasiri et

50 al., 2020; Gonsioroski et al., 2020).

51 In the environment, pharmaceuticals are found not only as active molecules (i.e. parent

52 compounds), but also as metabolites and biotic or abiotic transformation products (TPs) (Patel

53 et al., 2019). Pharmaceuticals are first transformed in the human or animal body after uptake.

54 They are partially metabolized into more polar and soluble forms (pharmacologically active

55 or not) by a variety of oxidative and conjugative enzymes (glucuronide conjugation, 56 sulfoconjugation, acetylation, amino acid conjugation, glutathione conjugation and

57 methylation) (Jančová \& Šiller, 2012). These transformations facilitate their elimination

58 through urine and faeces. Other transformation pathways occur in wastewaters during their

59 treatment in WWTPs. Pharmaceutical compounds and their metabolites are transformed by

60 biodegradation and physicochemical reactions (e.g. hydrolytic cleavage of amide bonds, ether

61 cleavage, demethylation, hydroxylation...) during secondary treatment (Quintana et al., 2005;

62 Barra Caracciolo et al., 2015). Once released in the environment, pharmaceutical compounds

63 and their metabolites are further transformed by direct photodegradation initiated by sunlight,

64 or indirect photodegradation in the presence of free radicals or singlet oxygen (generated by

65 the action of UV rays on natural organic matter) (Andreozzi et al., 2003). Chemical 66 hydrolysis and oxydo-reduction reactions can also lead to their transformation (as a function

67 of $\mathrm{pH}$ and temperature). Another main transformation route in the aquatic environment

68 involves biodegradation by different families of microorganisms if the molecules toxicities do

69 not inhibit microbial activity (Barra Caracciolo et al., 2015).

70 While the presence of pharmaceutical compounds in natural waters has been demonstrated 71 since the 1980s (Patel et al., 2019), many studies report an accumulation of these 
contaminants in other aquatic compartments (Kümmerer, 2004). Thus, sediments can

73 accumulate pharmaceutical compounds or their metabolites and TPs (Li et al., 2014; Tamtam

74 et al., 2011) but also favor microbial degradation processes (Kunkel \& Radke, 2008). Several

75 studies have reported significant accumulation of pharmaceuticals in benthic organisms: river

76 biofilms (Aubertheau et al., 2017; Huerta et al., 2016) and invertebrates (Burket et al., 2019;

77 de Solla et al., 2016; Du et al., 2015; Xie et al., 2019), as well as in fish (Brooks et al., 2005;

78 Huerta et al., 2013; Xie et al., 2019). Only aquatic plants seem not to accumulate these 79 compounds, or only weakly (Wilkinson et al., 2018). Such a widespread presence of pharmaceuticals makes it evident that metabolites and TPs of pharmaceutical residues could also be present in many of these compartments. The issue is all the more important because metabolites and TPs can exhibit toxicity to living organisms, which can be lower, similar, or even higher than the parent compounds (Bleeker et al., 1999; Bort et al., 1999; Bourgeois \& Wad, 1984; Schulze et al., 2010). However, the risks associated with these metabolites and TPs, as well as their presence in the environment, are still very little studied due to their very large number and the absence of analytical standards for their quantification.

Questioning relating to the presence of organic contaminants metabolites and TPs in natural waters and drinking water are emerging more and more worldwide. This is largely due to the knowledge gained on pesticide metabolites and their incidence on health. In France and other European countries, the presence of pesticide residues and their metabolites in water intended for human consumption is regulated by Council Directive 98/83/EC which sets quality limits for pesticides and their relevant metabolites of $0.1 \mu \mathrm{g} \mathrm{L}^{-1}$ per individual substance and $0.5 \mu \mathrm{g}$ $\mathrm{L}^{-1}$ for the sum of these molecules (European Council, 1998). To date, no regulation relating to the quality of natural waters includes pharmaceutical residues. However, six molecules or families of molecules (17-alpha-ethinylestradiol, 17-beta-estradiol, estrone, macrolide antibiotics, amoxicillin, ciprofloxacin) are included on the Watch list of substances for Union- 
97 wide monitoring established in 2018 by Implementing Decision (EU) 2018/840 (European

98 Commission, 2018).

99 The issue of risk assessment is today very important because of the rise of all sorts of 100 emerging pollutants that form an "environmental soup" of a multitude of compounds, in large 101 majority at low concentrations. Indeed, it has been shown that organic pollutants may have 102 unpredictable biochemical interactions when mixed together, leading to different effects of 103 what might be observed when evaluating the toxicity of a single molecule (Filby et al., 2007;

104 Sumpter \& Johnson, 2005).

105 The present work draws up a first assessment of the contamination of the aquatic environment 106 by pharmaceutical metabolites and TPs. Thus, two "iconic" pharmaceutical compounds 107 (carbamazepine - CBZ and diclofenac - DCF) and eight of their associated metabolites and 108 TPs were quantified in water, sediments, biofilms, and clams (Corbicula fluminea) from 109 rivers of Western France. Then, the QSAR toolbox (OECD \& European Chemicals Agency, 110 2020) was used to predict the missing toxicity data for these compounds considered 111 individually or in mixtures. This allowed a first environmental risk assessment in French 112 waters and sediments and then to open the discussion about the relevance of considering 113 pharmaceutical metabolites and TPs for future guidelines and regulations.

\section{Material and methods}

\section{2.1.Target compounds}

116 Carbamazepine, Diclofenac, and the metabolites and TPs considered in this work are

117 presented in Table 1. Analytical grade standards of carbamazepine (CBZ), 3118 hydroxycarbamazepine (3OH-CBZ), 10,11-epoxycarbamazepine (CBZ-epox), dibenzazepine 119 (Dibenz), acridone (Acrid), diclofenac (DCF), 4'-hydroxydiclofenac (4'OH-DCFBZ) and 5- 
hydroxydiclofenac (5OH-DCF) were purchased from Sigma-Aldrich (Darmstadt, Germany),

121 while standards of 10,11-dihydro-10,11-trans-dihydroxycarbamazepine (Trans-CBZ) and 2-

122 [(2-chlorophenyl)-amino]-benzaldehyde (Benz) were purchased from Santa Cruz

123 Biotechnology (Heidelberg, Germany) and Synchem UG \& Co. KG (Altenburg, Germany),

124 respectively. Individual stock solutions were prepared in LC-MS grade methanol (Carlo Erba

125 Reagents, Val de Reuil, France) at $200 \mathrm{mg} \mathrm{L}^{-1}$ and stored at $-20{ }^{\circ} \mathrm{C}$.

126

127 141 fluminea) with a size $>16 \mathrm{~mm}$ were collected by hand. All samples were transferred to clean

142 PEHD bottles and stored in a cool box until the end of the sampling day.

\subsection{Study area and sampling strategy}

A sampling campaign was conducted in September 2018 along three rivers (Vienne, Clain and Thouet) located in the same part of Western France (North of the Vienne and South of the Deux-Sèvres French departments) (Figure 1). Their watersheds present close rural/urban occupation, agricultural/socio-economic activities, and hydro-climatic conditions. They are typical of this part of France. The sampling took place at the end of summer, during the lowwater flow period, thus facilitating accessibility to the studied compartments.

Ten different sampling sites were selected based on their location: upstream or downstream from urban areas (Figure 1). On each site, a surface of $20 \mathrm{~m}^{2}$ was prospected to collect samples of all four compartments of interest. Thus, $2 \mathrm{~L}$ of water were grab sampled in a highdensity polyethylene (PEHD) bottle. Biofilms were collected from ten rocks chosen randomly at a depth of 50 to $100 \mathrm{~cm}$. For that, rock surface was scrapped with a clean toothbrush and ultrapure water (Milli-Q IQ 7000, Merck KGaA, Darmstadt, Germany). Bulk sample of surface sediment was collected as a composite sample, with a shovel, by pooling three samples at each location, and sieved on site to $<2 \mathrm{~mm}$. Approximately 100 clams $(C$. PEHD bottles and stored in a cool box until the end of the sampling day.

\subsection{Extraction of target compounds}


144 Target analytes were extracted from solid matrices (i.e. biofilms, sediments and clams) using 145 pressurized liquid extraction (PLE) (ASE 350, Thermo Scientific Inc., Waltham, USA) 146 followed by solid phase extraction (SPE) (Autotrace 150, Thermo Scientific Inc., Waltham, 147 USA). The method developed by Aubertheau et al. (2017) was used for biofilms and 148 sediments, while the method developed by Alvarez-Muñoz et al. (2015) was adapted for $C$. 149 fluminea. Tables SI-1 and SI-2 summarize the conditions used by matrix. For each sample, 150 two extraction cells were prepared. Each of the two obtained extracts was diluted with 151 ultrapure water to $500 \mathrm{~mL}$ for biofilms and $C$. fluminea, and to $1 \mathrm{~L}$ for sediments, and loaded 152 on two SPE cartridges. Then, the four obtained extracts were evaporated to dryness under a 153 gentle stream of nitrogen at $30^{\circ} \mathrm{C}$ (TurboVap LV, Biotage AB, Uppsala, Sweden). Finally, 154 they were each recovered in methanol/water $(10 / 90 ; \mathrm{v} / \mathrm{v})$ spiked with increasing 155 concentrations of a standards mixture (final concentrations of $0,0.02,0.05$ and $0.1 \mathrm{mg} \mathrm{L}^{-1}$ ) for 156 standard addition quantification.

157 Recoveries were determined by spiking each matrix with all analytes to a concentration of $158400 \mathrm{ng} \mathrm{g}^{-1}$ dry weight and allowing it to dry overnight in the dark at room temperature, before 159 performing extraction and analysis. This procedure was repeated three times. Recoveries were 160 between $19-123 \%$ for biofilms, 30-190 \% for sediments, and 37-142\% for clams (see Table 161 SI-3)

$1622 \mathrm{~L}$ of each water sample were filtered through a $0.45 \mu \mathrm{m}$ PVDF membrane (Durapore, 163 Merck KGaA, Darmstadt, Germany) before SPE extraction of compounds on Oasis HLB (6 164 cc, $200 \mathrm{mg}$ ) cartridges (Waters Corporation, Milford, USA). Table SI-4 shows the extraction 165 conditions. Samples were each loaded on four cartridges, and the four obtained extracts 166 underwent evaporation and restitution with the same conditions as solid matrices.

\section{2.4.Quantification of target compounds}


168 Compounds were separated using ultra high performance liquid chromatography (UHPLC) 169 (UltiMate 3000, Thermo Scientific Inc., Waltham, USA) on an Acquity UPLC BEH C18 170 column (2.1 x $100 \mathrm{~mm}, 1.7 \mu \mathrm{m}$; Waters Corporation, Milford, USA) kept at $30{ }^{\circ} \mathrm{C}$. A flow

171 rate of $0.4 \mathrm{~mL} \mathrm{~min}^{-1}$ was used with a mobile phase composed of water and methanol, both 172 acidified with $0.1 \%$ formic acid. A gradient ranging from $10 \%$ to $99 \%$ of methanol in 13 173 min was applied.

174 The UHPLC system was coupled with a hybrid quadrupole - time-of-flight (Q-ToF) mass 175 spectrometer (Impact HD QTOF, Bruker GmbH, Champs sur Marne, France) equipped with 176 an electrospray ion source (ESI) and operated in broadband collision-induced dissociation 177 (bbCID) mode. The mass range was from 150 to $500 \mathrm{~m} / \mathrm{z}$, the capillary tension was set to $1782700 \mathrm{~V}$, the dry gas flow rate was $4.0 \mathrm{~L} \mathrm{~min}^{-1}$, and the dry temperature $250{ }^{\circ} \mathrm{C}$. Table SI-5 179 lists the retention times and the exact ionized masses used for identifying all compounds. 1804 4'OH-DCF and 5OH-DCF were subsequently grouped together as "OH-DCF" due to poor 181 chromatographic separation.

182 Quantification by standard addition was chosen to normalise for matrix effects. In addition, 183 the analytical method's performance was assessed via linearity, limits of detection and 184 quantification, repeatability and reproducibility, according to the French AFNOR XP T90-210 185 standard (AFNOR, 1999) (detailed methods are presented in SI-6 and Table SI-7). All limits 186 of detection and quantification are summarized in Table SI-8.

\subsection{Metabolites and TPs ecotoxicity}

\subsubsection{Prediction of ecotoxicity data}

189 Ecotoxicity data of pharmaceutical metabolites or transformation products are often rare or 190 even not available at all. For this reason, the OECD Quantitative Structure Activity 
191 Relationship (QSAR) Toolbox (version 4.4) was used to generate environmental toxicity endpoints. This toolbox was developed by the Laboratory of Mathematical Chemistry (OASIS LMC, Bourgas, Bulgaria) for the OECD, in collaboration with the European Chemicals Agency (ECHA). Its main objective is to use QSAR methodologies to group chemicals into categories depending on their structure and/or modes of action. This helps to fill data gaps for a given compound based on the data available for its analogues, by read-across (used for qualitative endpoints), trend analysis (used for quantitative endpoints if a high number of analogues with experimental results are identified) or QSAR models. Blázquez et al. (2020) determined the acute toxicity for aquatic organisms of a biocidal active substance and its metabolites to assess the suitability of available QSAR models to predict the obtained values. The advantages of the OECD QSAR Toolbox were also detailed by Schultz et al. (2018).

In this study, the trend analysis approach was used to estimate acute toxicities of individual compounds with respect to the green algae Pseudokirchneriella subcapitata $\left(\mathrm{EC}_{50}\right.$, growth rate, $96 \mathrm{~h}$ ), the invertebrate Daphnia magna ( $\mathrm{LC}_{50}$, mortality, $48 \mathrm{~h}$ ), and the fish Pimephales promelas $\left(\mathrm{LC}_{50}\right.$, mortality, $\left.96 \mathrm{~h}\right)$. This approach involves modeling the relationship between the considered toxicity endpoint and a physicochemical property (by default, the Log $\mathrm{K}_{\mathrm{OW}}$ ), using the experimental data available for the compound's analogues.

The toxicity estimations obtained for the individual molecules were also used for the prediction of the acute toxicity of a mixture of parent molecule and its associated metabolites and TPs, respecting the molar fractions observed from the average concentrations measured in the studied waters (OECD, 2020). For the two mixtures considered (CBZ and its metabolites and TPs; DCF and its metabolites and TPs), it appears that the compounds exhibit different modes of action according to the acute aquatic toxicity classification by Verhaar (Modified), the ECOSAR (ECOSAR is the Ecological Structure Activity Relationships predictive model developed by the US-EPA) classification for aquatic toxicity, and the acute aquatic toxicity 
216 modes of action classification by OASIS (OASIS is the laboratory that developed the QSAR

217 Toolbox). Consequently, trend analysis calculations were performed considering an

218 independent modes of action approach (OECD, 2020).

219 2.5.2. Environmental risk assessment

220 According to the ECHA guidelines (European Chemicals Agency, 2008), experimental or

221 calculated toxicity endpoints cannot be directly used for an environmental risk assessment

222 because natural conditions are different than laboratory test conditions. Indeed, ecosystems

223 are more sensitive to chemical compounds than individual organisms in a laboratory

224 environment. For this reason, these endpoints $\left(\mathrm{LC}_{50}\right.$ or $\left.\mathrm{EC}_{50}\right)$ are used for the estimation of

225 predicted no effect concentrations in water $\left(\mathrm{PNEC}_{\text {water }}\right)$. $\mathrm{PNEC}_{\text {water }}$ are obtained by dividing

226 the lowest ecotoxicity value by an appropriate assessment factor. The scarcer the available

227 data, the higher is the applied assessment factor. In this study, only short-term toxicity data

228 were available. The estimation of effects on organisms throughout their life cycle was

229 therefore less realistic than with long-term data. Hence, a high assessment factor of 1000 was

230 applied (European Chemicals Agency, 2008).

231 Then, the hazard quotient (HQ) was calculated by dividing the maximal environmental

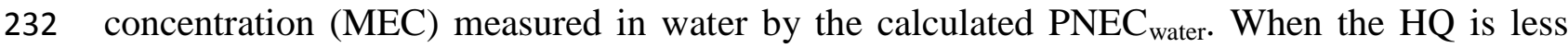

233 than 0.1 , the concerned compound does not present any risk for aquatic organisms. An HQ 234 between 0.1 and 1 indicates a medium risk, while a value above 1 means that the studied 235 molecule exhibits a high risk for the aquatic ecosystem (Straub, 2002).

236 For the sediment, no ecotoxicity parameter could be predicted by the QSAR Toolbox. 237 Therefore, the equilibrium partitioning method (EPM), described in the European Chemicals 238 Bureau technical guidance document (European Chemicals Bureau, 2003), was used to derive 239 a $\mathrm{PNEC}_{\text {sediment }}$ from the $\mathrm{PNEC}_{\text {water. }}$ Thus, $\boldsymbol{P N E C _ { \text { sediment } }}=\left(\mathbf{0 . 7 8 3}+\mathbf{0 . 0 2 1 7} * \boldsymbol{K}_{\boldsymbol{O}}\right) *$ 


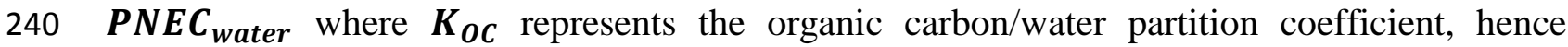
241 providing an estimate of the ability of a compound to be adsorbed on the organic matter of the

242 sediment. Indeed, a Log $\mathrm{K}_{\mathrm{OC}}$ greater than 3 indicates potentially significant adsorption on the 243 sediment (Tissier et al., 2005). Therefore, the $\mathrm{PNEC}_{\text {sediment }}$ value is associated with the 244 presence of organic matter in the sediment. The MEC is expressed in micrograms of pollutant 245 per gram of dry sediment, without consideration of organic carbon content, which is of $1 \%$ 246 on average for this study's sediments. For the calculation of HQ, the corrected MEC was used 247 to consider the part of organic carbon present in the sediment.

\section{Results and discussion}

\subsection{Occurrence of pharmaceutical metabolites and TPs in rivers}

250 All studied metabolites and TPs and their parent compounds were found in all samples from 251 the three rivers. This finding highlights the large occurrence of pharmaceutical metabolites 252 and TPs in the aquatic environment. Figure 2 and Figure 3 show mean concentrations $( \pm$ standard deviation) of DCF and CBZ with their associated metabolites and TPs in waters,

254 biofilms, sediments, and clams (N.B.: full data are presented in Table SI-9).

255 For the CBZ family, mean concentrations in water range from $0.18 \pm 0.09 \mu \mathrm{g} \mathrm{L}^{-1}$ for Trans$256 \mathrm{CBZ}$ to $0.52 \pm 0.13 \mu \mathrm{g} \mathrm{L}^{-1}$ for CBZ. In biofilms, concentrations are between $258 \pm 181 \mathrm{ng} \mathrm{g}^{-1}$ 257 for Trans-CBZ and $1735 \pm 811 \mathrm{ng} \mathrm{g}^{-1}$ for Dibenz. In sediments, concentrations are between 48 $258 \pm 25 \mathrm{ng} \mathrm{g}^{-1}$ for $3 \mathrm{OH}-\mathrm{CBZ}$ and $128 \pm 56 \mathrm{ng} \mathrm{g}^{-1}$ for Dibenz. Finally, in clams, levels range from $259345 \pm 218 \mathrm{ng} \mathrm{g}^{-1}$ for Trans-CBZ to $1066 \pm 566 \mathrm{ng} \mathrm{g}^{-1}$ for Acrid. These results show that mean 260 concentrations of Dibenz are higher than those of $\mathrm{CBZ}$ in most matrices. Acrid is also found 261 at levels close to those of CBZ. The other metabolites and TPs are generally less concentrated.

262 For the DCF family, the data show that metabolites and TPs are more concentrated than the 263 parent compound. Thus, mean concentrations in waters range from $0.19 \pm 0.27 \mu \mathrm{g} \mathrm{L^{-1 }}$ for 
264 Benz to $0.26 \pm 0.15 \mu \mathrm{g} \mathrm{L}^{-1}$ for OH-DCF. In biofilms, levels vary from $348 \pm 349 \mathrm{ng} \mathrm{g}^{-1}$ for 265 DCF to $2153 \pm 1532 \mathrm{ng} \mathrm{g}^{-1}$ for Benz. In sediments, concentrations range from $51 \pm 55 \mathrm{ng} \mathrm{g}^{-1}$ 266 for DCF to $229 \pm 250 \mathrm{ng} \mathrm{g}^{-1}$ for Benz. Finally, in clams, concentrations are between $493 \pm$ $267428 \mathrm{ng} \mathrm{g}^{-1}$ for DCF and $1149 \pm 916 \mathrm{ng} \mathrm{g}^{-1}$ for OH-DCF.

268 It is worth noting that CBZ and its metabolites and TPs are generally present at higher 269 concentrations than DCF and its metabolites and TPs in water and sediments, while DCF and 270 its metabolites and TPs are more accumulated than CBZ and its metabolites and TPs in 271 biofilms (especially Benz) and clams.

272 As shown in Table 2, in waters, CBZ concentrations are close to the levels determined by 273 Koba et al. (2018) in a Czech pond used for the tertiary treatment of wastewater effluent (290

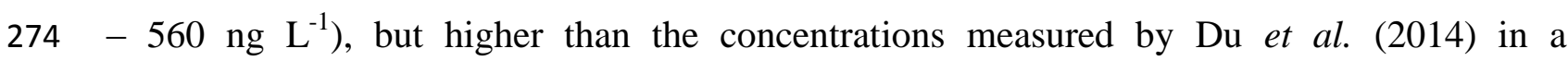
275 watercourse impacted by WWTP releases in central Texas, United States $\left(370 \pm 14 \mathrm{ng} \mathrm{L}{ }^{-1}\right)$. 276 DCF levels are of the same order of magnitude as those determined by Koba et al. (2018) (22 $\left.277-870 \mathrm{ng} \mathrm{L}^{-1}\right)$, or by Wilkinson et al. (2017) in three rivers of southern England $(<0.96-253$

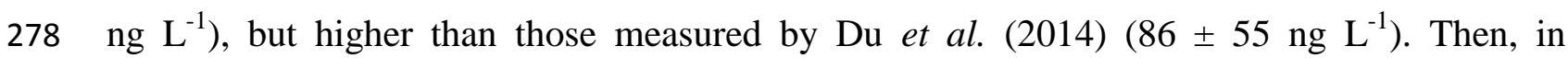
279 biofilms, the levels of CBZ are higher than those measured by Aubertheau et al. (2017) in the 280 Vienne River. For example, at the downstream site of the Châtellerault WWTP, the CBZ 281 concentration in this study is $1095 \pm 28 \mathrm{ng} \mathrm{g}^{-1}$, while in the study by Aubertheau et al. (2017) 282 it was $583.5 \mathrm{ng} \mathrm{g}^{-1}$. Likewise for the DCF concentration, which amounts to $64 \pm 26 \mathrm{ng} \mathrm{g}^{-1}$ at 283 the downstream site of the Châtellerault WWTP in this study, and to $37.2 \mathrm{ng} \mathrm{g}^{-1}$ in the study 284 by Aubertheau et al. (2017). In addition, in sediments, Koba et al. (2018) determined much 285 lower levels of CBZ $\left(5.1-16 \mathrm{ng} \mathrm{g}^{-1}\right)$ and DCF $\left(2.6-30 \mathrm{ng} \mathrm{g}^{-1}\right)$. Finally, CBZ was not 286 detected in clams from Taihu Lake in China (Xie et al., 2015), and DCF concentrations (1.41 $\left.287-5.42 \mathrm{ng} \mathrm{g}^{-1}\right)$ were lower than those measured in this study $\left(493 \pm 428 \mathrm{ng} \mathrm{g}^{-1}\right)$. 
288 Metabolites and TPs are much less studied than their related parent pharmaceuticals (Table 2).

289 Stülten et al. (2008) detected 4'OH-DCF and 5OH-DCF in WWTP effluents in Germany, at 290 concentrations higher than the levels measured in this study, up to $0.71 \mu \mathrm{g} \mathrm{L}^{-1}$ and $0.45 \mu \mathrm{g} \mathrm{L}^{-}$

$291^{1}$, respectively. In their study of a Canadian river, Miao \& Metcalfe (2003) did not detect $2923 \mathrm{OH}-\mathrm{CBZ}$ or CBZ-epox in any sample, but determined concentrations of Trans-CBZ of $2.2 \pm$ $2930.3 \mathrm{ng} \mathrm{L}^{-1}$, much lower than those measured in this study. Koba et al. (2018) detected CBZ294 epox and Trans-CBZ in a lagoon water at concentrations up to $71 \mathrm{ng} \mathrm{L}^{-1}$ (lower than in this 295 study) and $490 \mathrm{ng} \mathrm{L}^{-1}$ (higher than in this study), respectively, and in the sediment at 296 concentrations lower than the limit of quantification. Finally, Aubertheau et al. (2017) 297 detected CBZ-epox in the Vienne River biofilms with a maximal concentration estimated at $2985.3 \mathrm{ng} \mathrm{g}^{-1}$ which is lower than those determined in this study.

299 The distributions observed for the different compartments can be explained by several parameters/conditions which probably interact between them. First, the contamination of 301 biofilms, sediments, and clams depends on the compounds carried by water. However, the 302 composition of water can change rapidly (Ort et al., 2010) while that of solid matrices is 303 constrained by sorption/desorption kinetics (Gonzalez et al., 2012). Therefore, concentrations 304 measured in water samples represent an image of the contamination over a short period of 305 time while those determined in solid matrices are the result of accumulation over a certain 306 exposure period. This could explain the significant difference observed in the distribution of 307 compounds in water compared to the other matrices, especially for the DCF family for which 308 sediments and biofilms are characterized by a larger presence of Benz in comparison with 309 water. The differences are less significant for CBZ and its metabolites and TPs - especially 310 between water and sediment - but some compounds like Dibenz may have significant 311 variations in distributions. 
312 Another important parameter to consider is the partitioning of molecules which is generally

313 linked to their hydrophobicity (expressed via the octanol/water partition coefficient $-\mathrm{K}_{\mathrm{OW}}$ ).

$314 \mathrm{~K}_{\mathrm{OW}}$ is frequently used to predict the adsorption of pollutants to solids and thus their 315 bioaccumulation. Rogers (1996) provided a general rule for the application of $\mathrm{K}_{\mathrm{OW}}$ to the 316 estimation of sorption: a $\log \mathrm{K}_{\mathrm{OW}}$ lower than 2.5 indicates a low sorption potential, a $\log$ $317 \mathrm{~K}_{\mathrm{OW}}$ between 2.5 and 4 indicates a medium sorption potential, and a Log $\mathrm{K}_{\mathrm{OW}}$ greater than 4 a high sorption potential. Therefore, the significant presence of DCF and its metabolites and 319 TPs in benthic organisms (biofilms, clams) is consistent with their higher Log $\mathrm{K}_{\mathrm{OW}}$. Those compounds are more hydrophobic than CBZ and its metabolites and TPs which exhibit higher

321 levels in water and sediments. Dibenz presents an exception (Log $\left.\mathrm{K}_{\mathrm{OW}}=4.06\right)$ and this is 322 reflected in its high accumulation in biofilms.

323 Finally, the presence of metabolites and TPs in the aquatic environment is also linked to 324 pharmaceutical compounds degradation pathways. For example, Phototransformation is the 325 main degradation pathway for DCF in the environment (Boreen et al., 2003), and it takes 326 place rapidly $\left(\mathrm{t}_{1 / 2}=9.6 \pm 1.2 \mathrm{~h}\right.$ (Poirier-Larabie et al., 2016)), with Benz identified as the most 327 stable product (Eriksson et al., 2010). This could explain the low proportion of DCF compared to its metabolites and TPs. Moreover, it is worth noting that Benz is more abundant 329 in matrices exposed to sunlight (biofilms, sediments) than in clams' flesh. CBZ, on the other 330 hand, is known to be persistent in the environment (Loos et al., 2009). This compound is one 331 of the least degraded/eliminated in wastewater treatment processes $(32.7 \% \pm 17.9 \%$ (Luo et al., 2014); < $0-23 \%$ (Jekel et al., 2015)), but leads to the formation of Dibenz and Acrid (Kosjek et al., 2009). These properties may explain the similarity between the distributions.

\subsection{Individual compounds ecotoxicities}

335 Ecotoxicity of pharmaceutical metabolites and TPs was assessed for three different aquatic trophic levels: algae (Pseudokirchneriella subcapitata), invertebrates (Daphnia magna) and 
337 fish (Pimephales promelas) (Figure 4). Values obtained from the QSAR Toolbox highlight that DCF and its metabolites and TPs (Benz and OH-DCF) have similar toxicities towards green algae $\left(\mathrm{EC}_{50} \sim 6.01 \mathrm{mg} \mathrm{L}^{-1}\right)$. For Daphnia, OH-DCF $\left(\mathrm{LC}_{50}=2.3 \mathrm{mg} \mathrm{L}^{-1}\right)$ is found to be about 40 times more toxic than DCF $\left(\mathrm{LC}_{50}=80.1 \mathrm{mg} \mathrm{L}^{-1}\right)$, while an abnormally high $\mathrm{EC}_{50}$ value was found for Benz $\left(2.8810^{15} \mathrm{mg} \mathrm{L}^{-1}\right)$ demonstrating the actual limitations of QSAR models to predict the toxicity of all compounds for all organisms (Boxall et al., 2004). Benz is 4 times more toxic $\left(\mathrm{LC}_{50}=2.71 \mathrm{mg} \mathrm{L}{ }^{-1}\right)$ for $P$. promelas than its parent compound $\left(\mathrm{LC}_{50}=\right.$ $11.2 \mathrm{mg} \mathrm{L}^{-1}$ ), while $\mathrm{OH}-\mathrm{DCF}$ has the same toxicity than $\mathrm{DCF}\left(\mathrm{LC}_{50}=10.7 \mathrm{mg} \mathrm{L}^{-1}\right)$.

In the CBZ family, Dibenz stands out from all the other compounds, being the most toxic for the three studied species. The other metabolites and TPs exhibit toxicities that are slightly higher, of the same order of magnitude or lower than that of the parent compound. Hence, for green algae, $3 \mathrm{OH}-\mathrm{CBZ}$ is as toxic as $\mathrm{CBZ}\left(\mathrm{EC}_{50} \sim 19.55 \mathrm{mg} \mathrm{L}^{-1}\right)$, while the other compounds are 10 to 70 times less toxic. Likewise, for P. promelas, CBZ-epox exhibits an $\mathrm{LC}_{50}$ value of the same order of magnitude as the parent compound $\left(\sim 44.7 \mathrm{mg} \mathrm{L}^{-1}\right)$, while the other metabolites and TPs are 3 to 6 times less toxic. On the other hand, for daphnia, 3OH-CBZ and CBZ-epox $\left(\mathrm{LC}_{50} \sim 36.5 \mathrm{mg} \mathrm{L}^{-1}\right)$ are about 3 times more toxic than $\mathrm{CBZ}$, Acrid is as toxic $\left(\mathrm{LC}_{50} \sim 105.45 \mathrm{mg} \mathrm{L}^{-1}\right)$ and Trans-CBZ 65 times less toxic.

All these results are in agreement with the study of Pereira et al. (2020). Indeed, in their systematic review on the experimental and estimated toxicities of selected pharmaceuticals in different aquatic compartments, these authors found that DCF and its metabolite 4OH-DCF have similar toxicities to invertebrates and fish. In addition, they highlighted the higher toxicities of anti-inflammatory drugs, including DCF, as compared to antiepileptics such as CBZ. However, results differ regarding the most sensitive species. Indeed, while in our study results show that green algae is the most sensitive, followed by fish and daphnia, Pereira et al. (2020) observed that the most sensitive species were fish, followed by invertebrates and algae. 
362 Nevertheless, their observation was explained by the fact that part of the experimental data for

363 fish was obtained through cell line or tissue testing, making it difficult to extrapolate the

364 values to the entire organism.

\section{3.3.Mixtures ecotoxicities}

QSAR predictions were also used to assess mixtures ecotoxicities (including parent compound and its corresponding metabolites and TPs) since field data revealed their simultaneous presence in water and benthic organisms (biofilms, clams). Figure 4 also reports the predicted toxicities of mixtures of parent compounds with their associated metabolites and TPs.

The results show that the toxicity values of DCF or CBZ and their metabolites and TPs mixtures are overall in the middle range of the individual values predicted for the compounds. Thus, for Pimephales promelas, the mixture of CBZ and metabolites and TPs $\left(\mathrm{LC}_{50}=41.5\right.$ $\left.\mathrm{mg} \mathrm{L}^{-1}\right)$ is approximately 12 times less toxic than Dibenz alone $\left(\mathrm{LC}_{50}=3.27 \mathrm{mg} \mathrm{L}^{-1}\right)$. However, the mixture is 3 to 5 times more toxic than the other metabolites and TPs, when considered individually. According to the QSAR model, the mixture's toxicity is lower than CBZ's individual toxicity for Pimephales promelas $\left(41.5 \mathrm{mg} \mathrm{L}^{-1}\right.$ versus $\left.37.3 \mathrm{mg} \mathrm{L}^{-1}\right)$ and especially for the algae P. subcapitata $\left(37 \mathrm{mg} \mathrm{L}^{-1}\right.$ versus $\left.10.4 \mathrm{mg} \mathrm{L}^{-1}\right)$. On the contrary, the model predicts a higher toxicity of the mixture for daphnids. This highlights the importance of completing experimental ecotoxicological data to confirm mixture effects and hence the interest of considering metabolites and TPs along with their associated parent pharmaceutical compounds in the assessment of ecological risks. It is now known that effects resulting from the exposure to a mixture of organic contaminants can be very different from observations when evaluating the toxicity of a single compound, as it was already demonstrated for endocrine disruptors for example (Filby et al., 2007; Sumpter \& Johnson, 2005). Until now, few studies have been interested in this mixture effect with many pharmaceutical compounds, 
and even less with metabolites and TPs. Cleuvers (2003) showed that a mixture of CBZ and a

388 lipid lowering agent, clofibric acid, exhibited a higher toxicity than the single compounds at 389 the same concentration during immobilization tests of D. magna. The same author (Cleuvers, 390 2004) observed acute toxicity of a mixture of anti-inflammatories including DCF, at lower 391 concentrations than for the individual chemicals.

392 Wang et al. (2020) were the first to develop a QSAR model to predict mixture ecotoxicities of fluoroquinolone antibiotics with their photodegradation products for Escherichia coli. Their results showed that the mixture toxicity of fluoroquinolones derivatives is a concentration 395 addition of their individual toxicities. Qin et al. (2018) developed a QSAR model to predict 396 acute mixture ecotoxicities of two antibiotics and four pesticides towards Aliivibrio fischeri.

397 The 45 studied mixtures exhibited additive, synergistic, and antagonistic effects. The authors 398 also showed that, compared to traditional concentration additive and independent action 399 models, their QSAR model better predicted mixture toxicities.

400 3.4.Comparison with pesticide metabolites

401 Ecotoxicity values were also predicted for a common pesticide (atrazine - ATZ) and some of 402 its main metabolites (desethylatrazine - DEA, deisopropylatrazine - DIA, 403 desethyldeisopropylatrazine - DEDIA, hydroxyatrazine - OH-ATZ, and aniline) to compare 404 with CBZ, DCF and their metabolites and TPs (Figure 4). Atrazine was banned in France in 4052001 but is still found in waters and river sediments. Moreover, ATZ and its metabolite DEA 406 are frequently responsible for the downgrading of surface waters or groundwater quality. The 407 comparison with ATZ and its metabolites shows that although DCF and CBZ are less toxic to 408 the three species of interest than this pesticide, their metabolites and TPs exhibit $\mathrm{EC}_{50}$ and 409 LC $_{50}$ values broadly comparable to those of ATZ metabolites. 
410 As mentioned before, in France, the presence of pesticide residues and their metabolites in

411 waters is regulated by European Directive 98/83/EC (European Council, 1998) relating to the

412 quality of waters intended for human consumption. This text sets quality limits at $0.1 \mu \mathrm{g} \mathrm{L}^{-1}$

413 per individual substance and $0.5 \mu \mathrm{g} \mathrm{L}^{-1}$ for the sum. Water quality controls are increasingly

414 revealing situations where regulatory quality limits are exceeded for metabolites. Thus, the

415 French Directorate General of Health approached the ANSES to define a methodology for 416 identifying relevant metabolites (ANSES, 2019). Considering the possible effects of certain 417 pharmaceutical metabolites and TPs, this approach should be transposed to identify the most 418 relevant metabolites and TPs for human and/or environmental health.

\section{3.5.Risk assessment of target compounds in the studied rivers}

420 A methodology was developed to associate both ecotoxicity and persistence data to assess the

421 risk related to the presence of pharmaceutical metabolites and TPs in the sampled rivers.

422 Therefore, PNEC $_{\text {water }}$ were calculated from the predicted ecotoxicity endpoints for each 423 individual compound as well as for mixtures, then HQs were obtained by dividing the MEC 424 observed in waters during this study by the PNEC $_{\text {water }}$ (N.B.: a mixture's MEC is expressed as 425 the parent molecule's mass and corresponds to the sum of the individual compounds MECs).

426 Persistence was evaluated with the ultimate biodegradation index obtained with the 427 EPISUITE Biowin3 Survey Model included in the QSAR Toolbox (Environmental Protection 428 Agency, 2012). It should be noted that in this case, only biodegradation is considered in the 429 persistence, while other processes (hydrolysis, photolysis, etc.) may also transform/degrade 430 the compounds. For mixtures, the ultimate biodegradation index was obtained by calculating 431 the mixture's constituents' indexes weighted average. Biodegradation indexes vary between 4322.25 and 2.75 for the CBZ and DCF degradation compounds, which means half-life of a few 433 weeks to a few months, with the exception of Trans-CBZ (between 2.75 and 3.25) that 434 presents a slightly faster biodegradation than the other molecules. 
435 Figure 5 provides a classification of compounds according to their associated risk (HQ) for 436 the studied rivers and their biodegradation index. Target compounds can be divided in 4 437 groups: (1) "compounds already worrying" regarding their persistence and their high concentrations: OH-DCF, Benz and Dibenz. These compounds have an HQ lower than 1 ( 439 qualified as medium risk for aquatic organisms) and are therefore of concern only when 440 compared to the other studied compounds. The same applies for the notion of persistence in 441 water; (2) "compounds to watch out for" because of their persistence in the dissolved phase.

442 These molecules could become of concern if their levels tend to increase: DCF, CBZ, 3OH443 CBZ, CBZ-epox and Acrid. (3) "compounds to watch out for" because of how far they have 444 exceeded the PNEC $_{\text {water }}$ : no compound identified in this study; and (4) "compounds not of 445 concern" including compounds with a level of contamination below PNEC water $(\mathrm{HQ}<0.1)$ 446 and low persistence in dissolved phase: Trans-CBZ.

447 The same methodology was also involved to assess risk regarding the sediment compartment. 448 PNEC $_{\text {sediment }}$ were derived from the $\mathrm{PNEC}_{\text {water }}$ by the equilibrium partitioning method. The $449 \mathrm{~K}_{\mathrm{OC}}$ of a mixture is its constituents $\mathrm{K}_{\mathrm{OC}}$ values weighted average. The data thus calculated, as 450 well as the MEC values measured in the sediments of the three sampled rivers, were used to 451 deduce the HQs of each compound with respect to benthic organisms. Figure 6 presents the 452 classification of compounds according to their associated risk in the sediments of the studied 453 rivers and their biodegradation index. Consequently, OH-DCF and Benz are classified as 454 "compounds already worrying"; DCF, CBZ, 3OH-CBZ, CBZ-epox, and Dibenz are 455 "compounds to watch out for - group 2"; and Trans-CBZ is considered as a "compound not of 456 concern". Comparison between risks in water and sediments suggests that Dibenz is of higher 457 concern for aquatic species than for benthic organisms. The rest of the compounds present the 458 same risk in sediment and in water. In addition, the same behaviour is observed for the 
mixtures, in particular that of DCF and its metabolites and TPs which is of more concern than the parent compound alone.

461 The results also show the importance of considering mixtures and not only the parent 462 compounds, as illustrated by the case of DCF. Indeed, this compound - considered 463 individually - does not seem to represent a risk (i.e. group 2, Figures 5 and 6), while its

464 mixture with its metabolites and TPs is already worrying for the aquatic environment because 465 of their persistence and their high levels. However, this remark is not fully generalized since 466 CBZ alone and its mixture with metabolites and TPs show the same level of risk. This finding 467 suggests that it would be necessary to only identify compounds for which it is relevant.

\section{4. Conclusion}

469 Unsurprisingly, pharmaceutical metabolites and TPs have been found in waters, sediments, 470 biofilms, and clams of the studied rivers, obviously in varying concentrations, but in all 471 samples. This widespread distribution and occurrence presumably requires special attention, 472 at least as much as the presence of pesticide metabolites. Indeed, the use of QSAR models 473 made it possible to address the lack of experimental ecotoxicological data and to highlight 474 that some of $\mathrm{CBZ}$ or DCF metabolites and TPs could be more toxic than their parent 475 compounds for aquatic species. Thus, OH-DCF, Benz and Dibenz could represent a risk for 476 aquatic wildlife because of their relatively high hazard quotients and their relatively slow 477 biodegradation. The large number of possible metabolites and TPs and the possibility of 478 individual toxicity also raises questions about a "cocktail effect". Indeed, compounds may 479 have unpredictable biochemical interactions when considered in a mixture, resulting in 480 different (cumulative or not) effects than individual molecules. As shown by QSAR 481 predictions of mixtures, it appears that the risk for the aquatic environment is higher when one 482 considers DCF along with its metabolites and TPs. Nevertheless, our results also show that 
483 this is not generalizable for all parent compounds, e.g. CBZ. Consequently, it is urgent to

484 identify the most relevant metabolites and TPs - as is done for pesticides - to better prioritize 485 risk assessment.

486 For future works, it is important to complete the collected data by conducting sampling 487 campaigns at different times of the year and not only in summer. This would help better 488 understand the impact of seasonal variations on pharmaceutical molecules degradation 489 pathways and the presence and distribution of their metabolites and TPs in the aquatic 490 environment. Furthermore, it is important to acknowledge that QSAR modelling constitutes a 491 first estimation of pharmaceutical metabolites and TPs ecotoxicities as well as mixture effects. 492 Experimental data still need to be generated to confirm these calculations. Our findings 493 constitute a starting point for further research aimed to determine the risks coming from the 494 presence of pharmaceutical compounds along with their metabolites and TPs in the aquatic 495 environment, with the purpose of potentially including them in water management policies.

\section{Acknowledgements}

497 The authors acknowledge financial support from the European Union (ERDF) and "Région

498 Nouvelle Aquitaine". The authors thank Engineer Maha AL BADANY for her technical 499 support and valuable contribution to this work. 
501

502

AFNOR. (1999). XP T90-210 Water quality - Protocol for the evaluation of an alternative method of quantitative physicochemical analysis compared to a reference method. (French)

Alvarez-Muñoz, D., Huerta, B., Fernandez-Tejedor, M., Rodríguez-Mozaz, S., \& Barceló, D. (2015). Multi-residue method for the analysis of pharmaceuticals and some of their metabolites in bivalves. Talanta, 136, 174- 182. https://doi.org/10.1016/j.talanta.2014.12.035

Amarasiri, M., Sano, D., \& Suzuki, S. (2020). Understanding human health risks caused by antibiotic resistant bacteria $(\mathrm{ARB})$ and antibiotic resistance genes (ARG) in water environments: Current knowledge and questions to be answered. Critical Reviews in Environmental Science and Technology, 50(19), 2016- 2059. https://doi.org/10.1080/10643389.2019.1692611

Andreozzi, R., Raffaele, M., \& Nicklas, P. (2003). Pharmaceuticals in STP effluents and their solar photodegradation in aquatic environment. Chemosphere, 50(10), 1319- 1330. https://doi.org/10.1016/S0045-6535(02)00769-5

ANSES. (2019). Recommendation of the National Agency for Food, Environmental and Occupational Health Safety on the assessment of the relevance of pesticide metabolites in water intended for human consumption. (French)

Aubertheau, E., Stalder, T., Mondamert, L., Ploy, M.-C., Dagot, C., \& Labanowski, J. (2017). Impact of wastewater treatment plant discharge on the contamination of river biofilms by pharmaceuticals and antibiotic resistance. Science of The Total Environment, 579, 1387- 1398. https://doi.org/10.1016/j.scitotenv.2016.11.136

Barra Caracciolo, A., Topp, E., \& Grenni, P. (2015). Pharmaceuticals in the environment: Biodegradation and effects on natural microbial communities. A review. Journal of Pharmaceutical and Biomedical Analysis, 106, 25- 36. https://doi.org/10.1016/j.jpba.2014.11.040

Blázquez, M., Andreu-Sánchez, O., Ranero, I., Fernández-Cruz, M. L., \& Benfenati, E. (2020). Comparing in vivo data and in silico predictions for acute effects assessment of biocidal active substances and metabolites for aquatic organisms. Ecotoxicology and Environmental Safety, 205, 111291. https://doi.org/10.1016/j.ecoenv.2020.111291

Bleeker, E. A. J., Van Der Geest, H. G., Klamer, H. J. C., De Voogt, P., Wind, E., \& Kraak, M. H. S. (1999). Toxic and Genotoxic Effects of Azaarenes: Isomers and Metabolites. Polycyclic Aromatic Compounds, 13(3), 191- 203. https://doi.org/10.1080/10406639908020563

Boreen, A. L., Arnold, W. A., \& McNeill, K. (2003). Photodegradation of pharmaceuticals in the aquatic environment: A review. Aquatic Sciences, 65, 320- 341. https://doi.org/10.1007/s00027-0030672-7

Bort, R., Ponsoda, X., Jover, R., Gómez-Lechón, M. J., \& Castell, J. V. (1999). Diclofenac toxicity to hepatocytes: A role for drug metabolism in cell toxicity. The Journal of Pharmacology and Experimental Therapeutics, 288(1), 65- 72.

Bourgeois, B. F. D., \& Wad, N. (1984). Individual and combined antiepileptic and neurotoxic activity of carbamazepine and carbamazepine-10,11-epoxide in mice. The Journal of Pharmacology and Experimental Therapeutics, 231(2), 411- 415. 

Synthetic Chemicals Degrade in the Environment. Environmental Science \& Technology, 38(19), 368A-375A. https://doi.org/10.1021/es040624v

Brooks, B. W., Chambliss, C. K., Stanley, J. K., Ramirez, A., Banks, K. E., Johnson, R. D., \& Lewis, R. J. (2005). Determination of select antidepressants in fish from an effluent-dominated stream. Environmental Toxicology and Chemistry, 24(2), 464- 469. https://doi.org/10.1897/04-081R.1

Burket, S. R., White, M., Ramirez, A. J., Stanley, J. K., Banks, K. E., Waller, W. T., Chambliss C. K., \& Brooks, B. W. (2019). Corbicula fluminea rapidly accumulate pharmaceuticals from an effluent $\begin{array}{lllll}\text { dependent } & \text { urban } & \text { stream. } & \text { Chemosphere, } & \text { 883. }\end{array}$ https://doi.org/10.1016/j.chemosphere.2019.03.014

Cleuvers, M. (2003). Aquatic ecotoxicity of pharmaceuticals including the assessment of combination effects. Toxicology Letters, 142(3), 185- 194. https://doi.org/10.1016/S0378-4274(03)00068-7

Cleuvers, M. (2004). Mixture toxicity of the anti-inflammatory drugs diclofenac, ibuprofen, naproxen, and acetylsalicylic acid. Ecotoxicology and Environmental Safety, 59(3), 309- 315. https://doi.org/10.1016/S0147-6513(03)00141-6

Daughton C. G., \& Ternes T. A. (1999). Pharmaceuticals and personal care products in the environment: Agents of subtle change? Environmental Health Perspectives, 107(suppl 6), 907- 938. https://doi.org/10.1289/ehp.99107s6907

de Solla, S. R., Gilroy, È. A. M., Klinck, J. S., King, L. E., McInnis, R., Struger, J., Backus, S. M., \& Gillis, P. L. (2016). Bioaccumulation of pharmaceuticals and personal care products in the unionid mussel Lasmigona costata in a river receiving wastewater effluent. Chemosphere, 146, 486- 496. https://doi.org/10.1016/j.chemosphere.2015.12.022

Du, B., Haddad, S. P., Luek, A., Scott, W. C., Saari, G. N., Kristofco, L. A., Connors, K. A., Rash, C., Rasmussen, J. B., Chambliss, C. K., \& Brooks, B. W. (2014). Bioaccumulation and trophic dilution of human pharmaceuticals across trophic positions of an effluent-dependent wadeable stream. Philosophical Transactions of the Royal Society B: Biological Sciences, 369(1656), 20140058- 20140058. https://doi.org/10.1098/rstb.2014.0058

Du, B., Haddad, S. P., Scott, W. C., Chambliss, C. K., \& Brooks, B. W. (2015). Pharmaceutical bioaccumulation by periphyton and snails in an effluent-dependent stream during an extreme drought. Chemosphere, 119, 927- 934. https://doi.org/10.1016/j.chemosphere.2014.08.044

Environmental Protection Agency. (2012). Sustainable Futures / P2 Framework Manual 2012 EPA748-B12-001 5. Estimating Physical / Chemical and Environmental Fate Properties with EPI Suite ${ }^{\mathrm{TM}}$. Retrieved on February 10, 2021 from: https://www.epa.gov/sites/production/files/201505/documents/05.pdf

Eriksson, J., Svanfelt, J., \& Kronberg, L. (2010). A Photochemical Study of Diclofenac and Its Major Transformation Products. Photochemistry and Photobiology, 86(3), 528- 532. https://doi.org/10.1111/j.1751-1097.2009.00703.x

Escher, B. I., \& Fenner, K. (2011). Recent Advances in Environmental Risk Assessment of Transformation Products. Environmental Science \& Technology, 45(9), 3835- 3847. https://doi.org/10.1021/es1030799 
579 European Chemicals Agency. (2008). Guidance on information requirements and chemical safety 580 assessment. Chapter R.10: Characterisation of dose [concentration]-response for environment. 581 Retrieved on February $10, \quad 2021$ from: 582 https://echa.europa.eu/documents/10162/13632/information_requirements_r10_en.pdf/bb902be7-

583 a503-4ab7-9036-d866b8ddce69

584 European Chemicals Bureau. (2003). Technical guidance document on risk assessment in support of 585 the commission directive 93/67/EEC on risk assessment for new notified substances Commission 586 Regulation (EC) No 1488/94 on risk assessment for existing substances directive 98/8/EC of the 587 European Parliament and of the council concerning the placing of biocidal products on the market. 588 Retrieved on February 10, 2021 from: https://op.europa.eu/en/publication-detail/589

590 European Commission. Commission Implementing Decision (EU) 2018/840 of 5 June 2018 591 establishing a watch list of substances for Union-wide monitoring in the field of water policy pursuant 592 to Directive 2008/105/EC of the European Parliament and of the Council and repealing Commission 593 Implementing Decision (EU) 2015/495 (notified under document C(2018) 3362). , Pub. L. No. 594 32018D0840, 141 OJ L (2018).

595 European Council. Council Directive 98/83/EC of 3 November 1998 on the quality of water intended 596 for human consumption., Pub. L. No. 31998L0083, OJ L 330 (1998).

597 Fent, K., Weston, A. A., \& Caminada, D. (2006). Ecotoxicology of human pharmaceuticals. Aquatic 598 Toxicology, 76(2), 122- 159. https://doi.org/10.1016/j.aquatox.2005.09.009

599 Filby, A. L., Neuparth, T., Thorpe, K. L., Owen, R., Galloway, T. S., \& Tyler, C. R. (2007). Health 600 Impacts of Estrogens in the Environment, Considering Complex Mixture Effects. Environmental 601 Health Perspectives, 115(12), 1704- 1710. https://doi.org/10.1289/ehp.10443

602 Foster, H. R., Burton, G. A., Basu, N., \& Werner, E. E. (2010). Chronic Exposure to Fluoxetine 603 (Prozac) Causes Developmental Delays in Rana pipiens Larvae. Environmental Toxicology and 604 Chemistry, 29(12), 2845- 2850. https://doi.org/10.1002/etc.345

605 Gonsioroski, A., Mourikes, V. E., \& Flaws, J. A. (2020). Endocrine Disruptors in Water and Their 606 Effects on the Reproductive System. International Journal of Molecular Sciences, 21(6). 607 https://doi.org/10.3390/ijms21061929

608 Gonzalez, J.-L., Bouchoucha, M., Chiffoleau, J.-F., \& Andral, B. (2012). RINBIO 2011 experiment. 609 Monitoring of the kinetics of chemical contamination of mussels (Mytillus galloprovincialis). 610 (French). Retrieved on February 10, 2021 from: 611 https://archimer.ifremer.fr/doc/00357/46855/46743.pdf

612 Huerta, B., Jakimska, A., Gros, M., Rodríguez-Mozaz, S., \& Barceló, D. (2013). Analysis of multi613 class pharmaceuticals in fish tissues by ultra-high-performance liquid chromatography tandem mass 614 spectrometry. Journal of Chromatography A, $1288, \quad 63-72$. 615 https://doi.org/10.1016/j.chroma.2013.03.001

616 Huerta, B., Rodriguez-Mozaz, S., Nannou, C., Nakis, L., Ruhí, A., Acuña, V., Sabater, S., \& Barcelo, 617 D. (2016). Determination of a broad spectrum of pharmaceuticals and endocrine disruptors in biofilm 618 from a wastewater treatment plant-impacted river. Science of The Total Environment, 540, 241- 249. 619 https://doi.org/10.1016/j.scitotenv.2015.05.049 
Jančová, P., \& Šiller, M. (2012). Phase II Drug Metabolism. In Topics on Drug Metabolism (J. Paxton). Retrieved on February 10, 2021 from: https://www.intechopen.com/books/topics-on-drugmetabolism/phase-ii-drug-metabolism

Jekel, M., Dott, W., Bergmann, A., Dünnbier, U., Gnirß, R., Haist-Gulde, B., Hamscher, G., Letzel, M., Licha, T., Lyko, S., Miehe, U., Sacher, F., Scheurer, M., Schmidt, C. K., Reemtsma, T., \& Ruhl, A. S. (2015). Selection of organic process and source indicator substances for the anthropogenically $\begin{array}{lllll}\text { influenced } \quad \text { water } & \text { cycle. } & \text { Chemosphere, } & 125, & 155\end{array}$ https://doi.org/10.1016/j.chemosphere.2014.12.025

Koba, O., Grabicova, K., Cerveny, D., Turek, J., Kolarova, J., Randak, T., Zlabek, V., \& Grabic, R. (2018). Transport of pharmaceuticals and their metabolites between water and sediments as a further potential exposure for aquatic organisms. Journal of Hazardous Materials, 342, 401- 407. https://doi.org/10.1016/j.jhazmat.2017.08.039

Kosjek, T., Andersen, H. R., Kompare, B., Ledin, A., \& Heath, E. (2009). Fate of Carbamazepine during Water Treatment. Environmental Science \& Technology, 43(16), 6256-6261. https://doi.org/10.1021/es900070h

Kümmerer, K. (2004). Pharmaceuticals in the Environment: Sources, Fate, Effects and Risks (Second Edition). Springer.

Kunkel, U., \& Radke, M. (2008). Biodegradation of Acidic Pharmaceuticals in Bed Sediments: Insight from a Laboratory Experiment. Environmental Science \& Technology, 42(19), 7273- 7279. https://doi.org/10.1021/es801562j

Li, Z., Maier, M. P., \& Radke, M. (2014). Screening for pharmaceutical transformation products formed in river sediment by combining ultrahigh performance liquid chromatography/high resolution mass spectrometry with a rapid data-processing method. Analytica Chimica Acta, 810, 61- 70. https://doi.org/10.1016/j.aca.2013.12.012

Liebig, M., Fernandez, Á. A., Blübaum- Gronau, E., Boxall, A., Brinke, M., Carbonell, G., Egeler, P., Fenner, K., Fernandez, C., Fink, G., Garric, J., Halling- Sørensen, B., Knacker, T., Krogh, K. A., Küster, A., Löffler, D., Cots, M. A. P., Pope, L., Prasse, C., Römbke, J., Rönnefahrt, I., Schneider, M. K., Schweitzer, N., Tarazona, J. V., Ternes, T. A., Traunspurger, W., Wehrhan, A., \& Duis, K. (2010). Environmental risk assessment of ivermectin: A case study. Integrated Environmental Assessment and Management, 6(S1), 567- 587. https://doi.org/10.1002/ieam.96

Loos, R., Gawlik, B. M., Locoro, G., Rimaviciute, E., Contini, S., \& Bidoglio, G. (2009). EU-wide survey of polar organic persistent pollutants in European river waters. Environmental Pollution, 157(2), 561- 568. https://doi.org/10.1016/j.envpol.2008.09.020

Luo, Y., Guo, W., Ngo, H. H., Nghiem, L. D., Hai, F. I., Zhang, J., Liang, S., \& Wang, X. C. (2014). A review on the occurrence of micropollutants in the aquatic environment and their fate and removal during wastewater treatment. Science of The Total Environment, 473-474, 619-641. https://doi.org/10.1016/j.scitotenv.2013.12.065

Margot, J., Magnet, A., Thonney, D., Chèvre, N., Alencastro, D., Felippe, L., \& Rossi, L. (2011). Treatment of micropollutants in wastewater - Final report on the pilot tests at the Vidy WWTP (Lausanne). (French). Retrieved on February 10, 2021 from: https://infoscience.epfl.ch/record/163236?ln=en 

site evaluation of the efficiency of conventional and advanced secondary processes for the removal of 60 organic micropollutants. Water Science and Technology, 62(12), 2970- 2978. https://doi.org/10.2166/wst.2010.989

Mazellier, P., Fuster, L., Budzinski, H., Garric, J., Couteau, J., \& Aït-Aïssa, S. (2018). Seine-Aval project 5 CRAPPSE "Contamination and Reactivity of Pesticides and Pharmaceuticals in the estuary of Seine". (French). Retrieved on February 10, 2021 from: https://www.seine-aval.fr/wpcontent/uploads/2017/02/RR-SA5-CRAPPSE.pdf

Miao, X.-S., \& Metcalfe, C. D. (2003). Determination of Carbamazepine and Its Metabolites in Aqueous Samples Using Liquid Chromatography-Electrospray Tandem Mass Spectrometry. Analytical Chemistry, 75(15), 3731- 3738. https://doi.org/10.1021/ac030082k

OECD. (2020). OECD (Q)SAR Toolbox v.4.4.1. Example for predicting Skin Sensitization of a mixture with known components. Retrieved on February 10, 2021 from: https://qsartoolbox.org/file/2020/04/Tutorial_10_Skin-Sensitization-of-mixture.pdf

OECD, \& European Chemicals Agency. (2020). QSAR Toolbox. Retrieved on February 10, 2021 from: https://qsartoolbox.org/

Ort, C., Lawrence, M. G., Reungoat, J., \& Mueller, J. F. (2010). Sampling for PPCPs in Wastewater Systems: Comparison of Different Sampling Modes and Optimization Strategies. Environmental Science \& Technology, 44(16), 6289- 6296. https://doi.org/10.1021/es100778d

Patel, M., Kumar, R., Kishor, K., Mlsna, T., Pittman, C. U., \& Mohan, D. (2019). Pharmaceuticals of Emerging Concern in Aquatic Systems: Chemistry, Occurrence, Effects, and Removal Methods. Chemical Reviews, 119(6), 3510- 3673. https://doi.org/10.1021/acs.chemrev.8b00299

Pereira, A., Silva, L., Laranjeiro, C., Lino, C., \& Pena, A. (2020). Selected Pharmaceuticals in Different Aquatic Compartments: Part II-Toxicity and Environmental Risk Assessment. Molecules, 25(8), 1796. https://doi.org/10.3390/molecules25081796

Petrovic, M., Solé, M., Alda, M. J. L. D., \& Barceló, D. (2002). Endocrine disruptors in sewage treatment plants, receiving river waters, and sediments: Integration of chemical analysis and biological effects on feral carp. Environmental Toxicology and Chemistry, 21(10), 2146- 2156. https://doi.org/10.1002/etc.5620211018

Poirier-Larabie, S., Segura, P. A., \& Gagnon, C. (2016). Degradation of the pharmaceuticals diclofenac and sulfamethoxazole and their transformation products under controlled environmental conditions. Science of The Total Environment, 557- 558, 257- 267. https://doi.org/10.1016/j.scitotenv.2016.03.057

Qin, L.-T., Chen, Y.-H., Zhang, X., Mo, L.-Y., Zeng, H.-H., \& Liang, Y.-P. (2018). QSAR prediction of additive and non-additive mixture toxicities of antibiotics and pesticide. Chemosphere, 198, 122- 129. https://doi.org/10.1016/j.chemosphere.2018.01.142

Quintana, J. B., Weiss, S., \& Reemtsma, T. (2005). Pathways and metabolites of microbial degradation of selected acidic pharmaceutical and their occurrence in municipal wastewater treated by a membrane bioreactor. Water Research, 39(12), 2654- 2664. https://doi.org/10.1016/j.watres.2005.04.068 
Rogers, H. R. (1996). Sources, behaviour and fate of organic contaminants during sewage treatment

702 and in sewage sludges. Science of The Total Environment, 185(1), 3- 26. https://doi.org/10.1016/0048-9697(96)05039-5

Schultz, T. W., Diderich, R., Kuseva, C. D., \& Mekenyan, O. G. (2018). The OECD QSAR Toolbox Starts Its Second Decade. In Computational Toxicology: Methods and Protocols (O. Nicolotti) (p. 55- 77). https://doi.org/10.1007/978-1-4939-7899-1_2

Schulze, T., Weiss, S., Schymanski, E., von der Ohe, P. C., Schmitt-Jansen, M., Altenburger, R., Streck, G., \& Brack, W. (2010). Identification of a phytotoxic photo-transformation product of diclofenac using effect-directed analysis. Environmental Pollution, 158(5), 1461- 1466. https://doi.org/10.1016/j.envpol.2009.12.032

Straub, J. O. (2002). Environmental risk assessment for new human pharmaceuticals in the European Union according to the draft guideline/discussion paper of January 2001. Toxicology Letters, 131(1), 137- 143. https://doi.org/10.1016/S0378-4274(02)00049-8

Stülten, D., Zühlke, S., Lamshöft, M., \& Spiteller, M. (2008). Occurrence of diclofenac and selected metabolites in sewage effluents. Science of The Total Environment, 405(1), 310-316. https://doi.org/10.1016/j.scitotenv.2008.05.036

Sumpter, J. P., \& Johnson, A. C. (2005). Lessons from Endocrine Disruption and Their Application to Other Issues Concerning Trace Organics in the Aquatic Environment. Environmental Science \& Technology, 39(12), 4321- 4332. https://doi.org/10.1021/es048504a

Tamtam, F., Le Bot, B., Dinh, T., Mompelat, S., Eurin, J., Chevreuil, M., Bonté, P., Mouchel, J.-M., \& Ayrault, S. (2011). A 50-year record of quinolone and sulphonamide antimicrobial agents in Seine River sediments. Journal of Soils and Sediments, 11(5), 852- 859. https://doi.org/10.1007/s11368011-0364-1

Tissier, C., Morvan, C., Bocquené, G., Grossel, H., James, A., \& Marchand, M. (2005). Priority substances of the Water Framework Directive (WFD). Summary sheets. (French). Retrieved on February 10, 2021 from: https://wwz.ifremer.fr/dce/content/download/35329/file/SubstancesDCE_ARC_2005.pdf

Wang, D., Ning, Q., Dong, J., Brooks, B. W., \& You, J. (2020). Predicting mixture toxicity and antibiotic resistance of fluoroquinolones and their photodegradation products in Escherichia coli. Environmental Pollution, 262, 114275. https://doi.org/10.1016/j.envpol.2020.114275

Wilkinson, J. L., Hooda, P. S., Swinden, J., Barker, J., \& Barton, S. (2017). Spatial distribution of organic contaminants in three rivers of Southern England bound to suspended particulate material and dissolved in water. Science of The Total Environment, 593- 594, 487- 497. https://doi.org/10.1016/j.scitotenv.2017.03.167

Wilkinson, J. L., Hooda, P. S., Swinden, J., Barker, J., \& Barton, S. (2018). Spatial (bio)accumulation of pharmaceuticals, illicit drugs, plasticisers, perfluorinated compounds and metabolites in river sediment, aquatic plants and benthic organisms. Environmental Pollution, 234, 864- 875. https://doi.org/10.1016/j.envpol.2017.11.090

Xie, H., Hao, H., Xu, N., Liang, X., Gao, D., Xu, Y., Gao, Y., Tao, H., \& Wong, M. (2019). Pharmaceuticals and personal care products in water, sediments, aquatic organisms, and fish feeds in the Pearl River Delta: Occurrence, distribution, potential sources, and health risk assessment. Science of The Total Environment, 659, 230- 239. https://doi.org/10.1016/j.scitotenv.2018.12.222 
743 Xie, Z., Lu, G., Liu, J., Yan, Z., Ma, B., Zhang, Z., \& Chen, W. (2015). Occurrence, bioaccumulation, 744 and trophic magnification of pharmaceutically active compounds in Taihu Lake, China. Chemosphere, 745 138, 140- 147. https://doi.org/10.1016/j.chemosphere.2015.05.086 
Compound

Carbamazepine

(CBZ)

3-Hydroxycarbamazepine (3OH-CBZ)

10,11-Epoxycarbamazepine (CBZ-epox)

10,11-dihydro-10,11-transdihydroxycarbamazepine (Trans-CBZ)

Dibenzazepine

(Dibenz)

Acridone

(Acrid)
Parent compound

Metabolite

Metabolite

Metabolite

58955-93-4

12.20

$-0.21$

Metabolite + WWTP degradation product

Metabolite + WWTP

degradation product

256-96-2 $19.50 \quad 4.06$

$578-95-0$

0.32

1.69

\section{CAS number}

$\mathbf{p K a}^{*}$

$\log K_{O W^{*}}$

Chemical structure
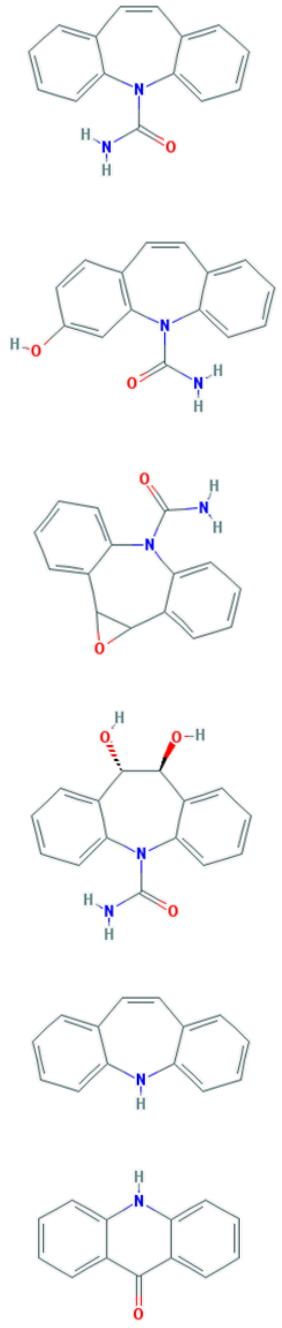

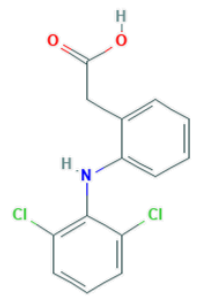

Diclofenac

(DCF)

Parent compound

15307-86-5

4.05

4.51

4'-Hydroxydiclofenac (4'OH-DCF)
Metabolite

64118-84-9

3.76

3.70 
5-Hydroxydiclofenac (5OH-DCF)

2-[(2-chlorophenyl)-amino]benzaldehyde (Benz)

\section{Metabolite}

69002-84-2

3.81

3.18

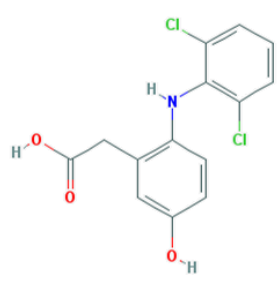

Photodegradation product

$71758-44-6$

8.18

3.65

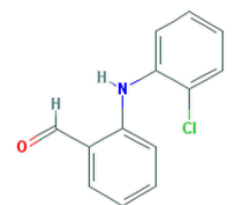

*Values predicted by the QSAR Toolbox (version 4.4)

752

753 
Table 2: Mean concentrations and comparison with literature.

755

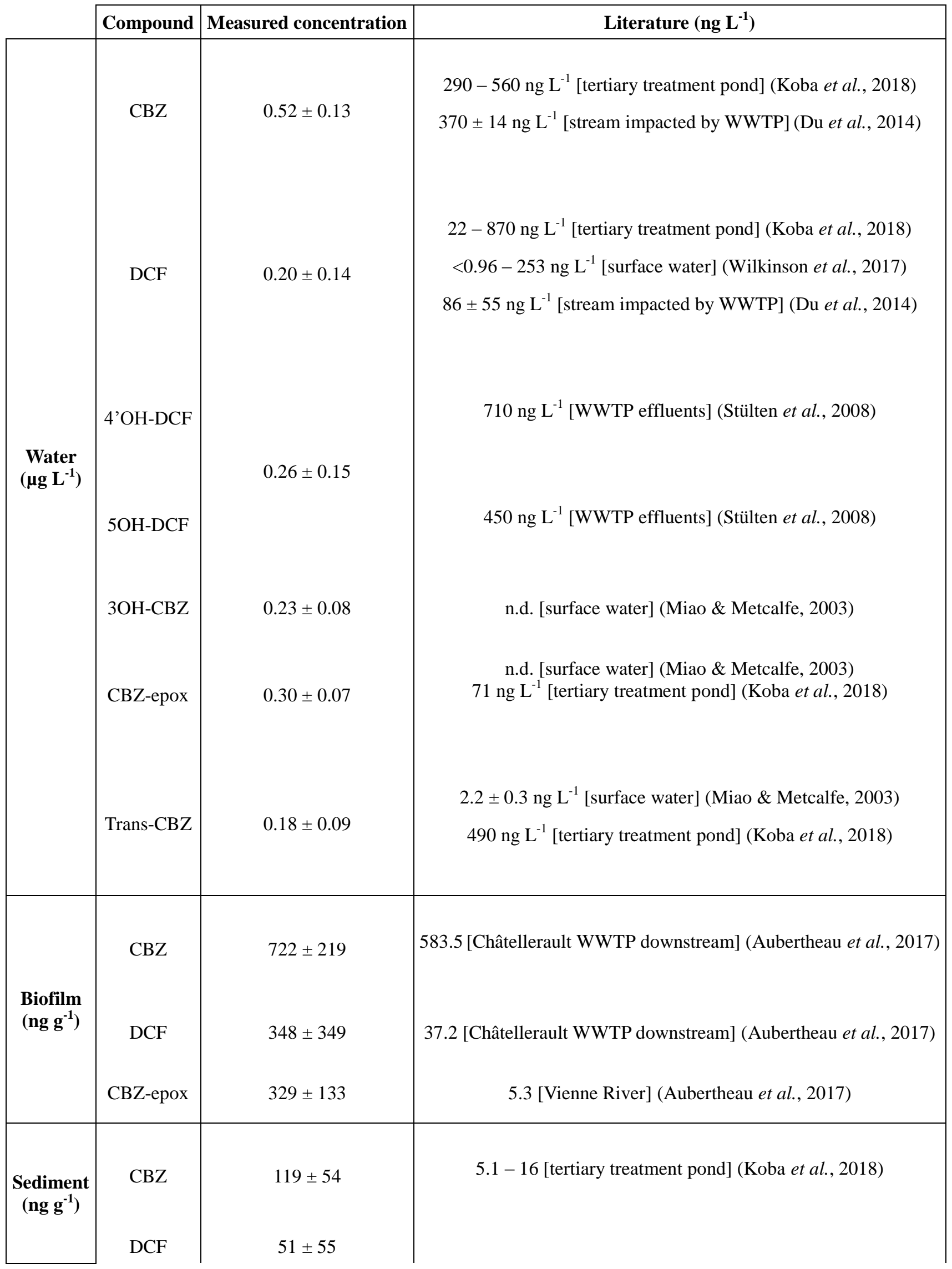




\begin{tabular}{|c|c|c|c|}
\hline & $\begin{array}{l}\text { CBZ-epox } \\
\text { Trans-CBZ }\end{array}$ & $\begin{array}{l}100 \pm 47 \\
57 \pm 39\end{array}$ & $\begin{array}{l}2.6-30 \text { [tertiary treatment pond] (Koba et al., 2018) } \\
<\text { LoQ [tertiary treatment pond] (Koba } \text { et al., 2018) } \\
<\text { LoQ [tertiary treatment pond] (Koba } \text { et al., 2018) }\end{array}$ \\
\hline $\begin{array}{c}\text { Clams } \\
\left(\mathrm{ng} \mathrm{g}^{-1}\right)\end{array}$ & $\begin{array}{l}\mathrm{CBZ} \\
\mathrm{DCF}\end{array}$ & $\begin{array}{l}962 \pm 381 \\
493 \pm 428\end{array}$ & $\begin{array}{c}<\text { LoD [lake] (Xie et al., 2015) } \\
1.41-5.42 \text { [lake] (Xie et al., 2015) }\end{array}$ \\
\hline
\end{tabular}

756

757 
758 Figure 1: Sampling sites; Up. = upstream, Down. = downstream; Black stars indicate 759 important cities located along the watersheds; Yellow marks indicate the locations of 760 sampling sites.
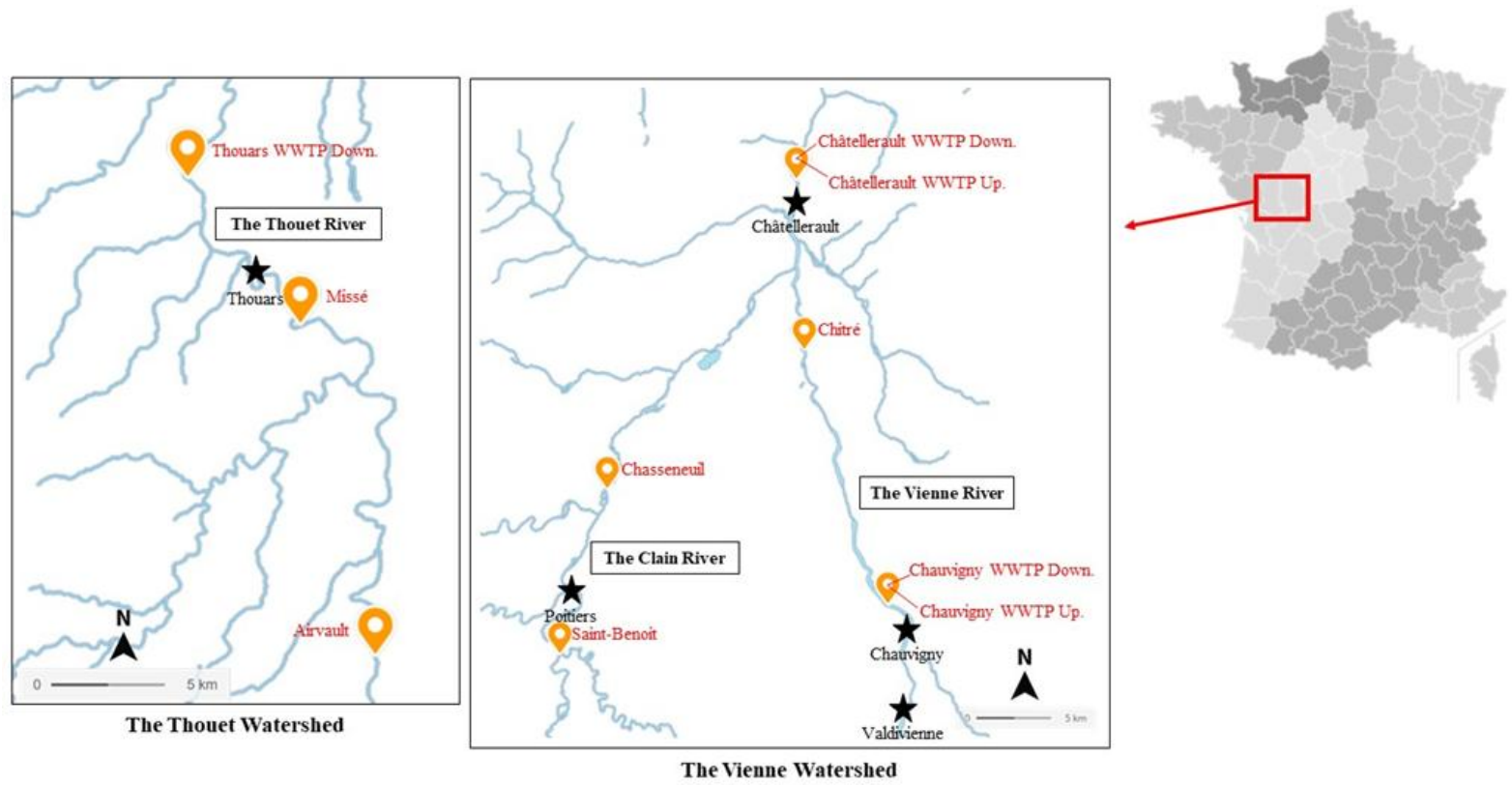
763 Figure 2: Mean levels ( \pm standard deviation) of DCF and its associated metabolites and 764 TPs in the compartments of interest, along the three studied rivers.

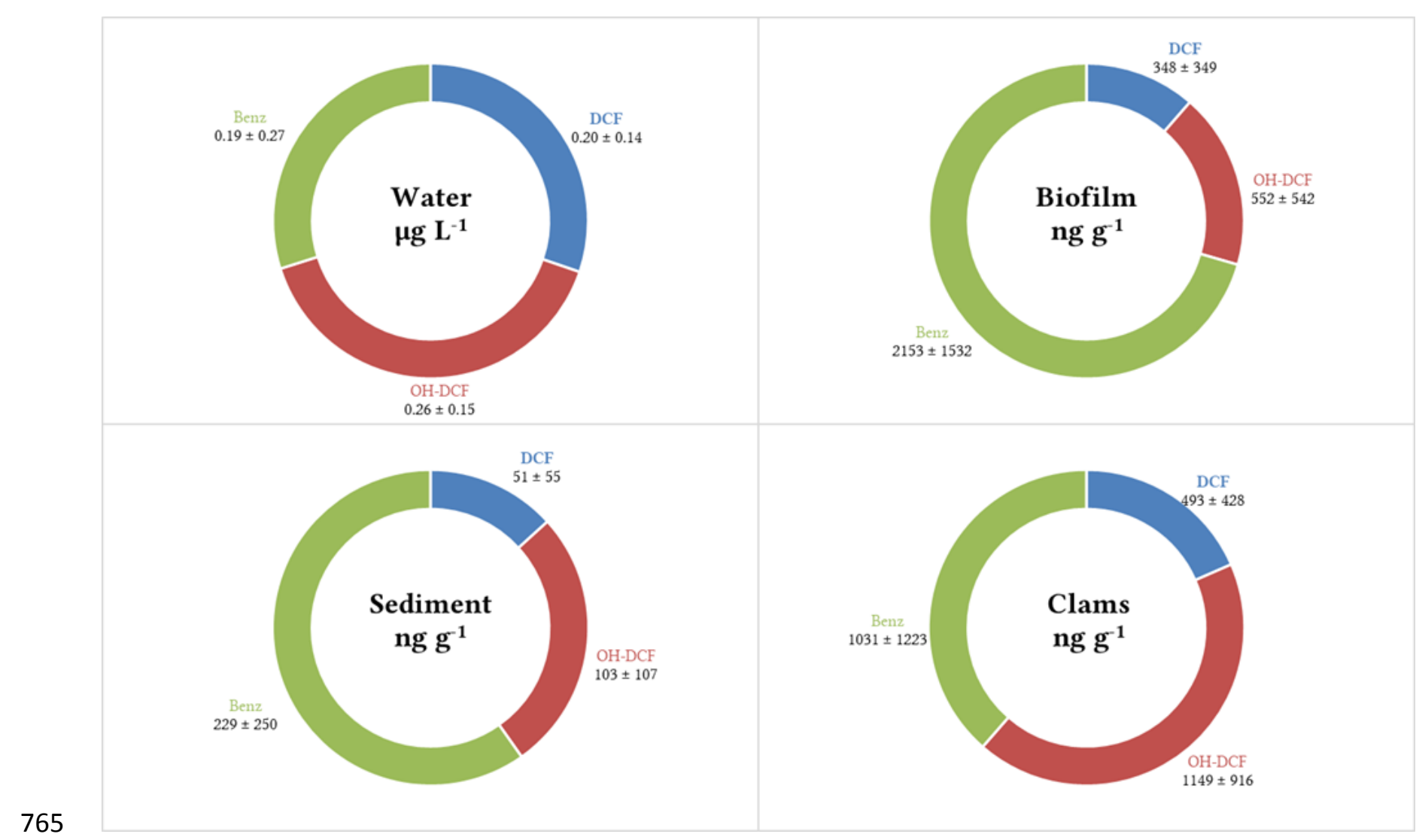


768 Figure 3: Mean levels of CBZ ( \pm standard deviation) and its associated metabolites and 769 TPs in the compartments of interest, along the three studied rivers.

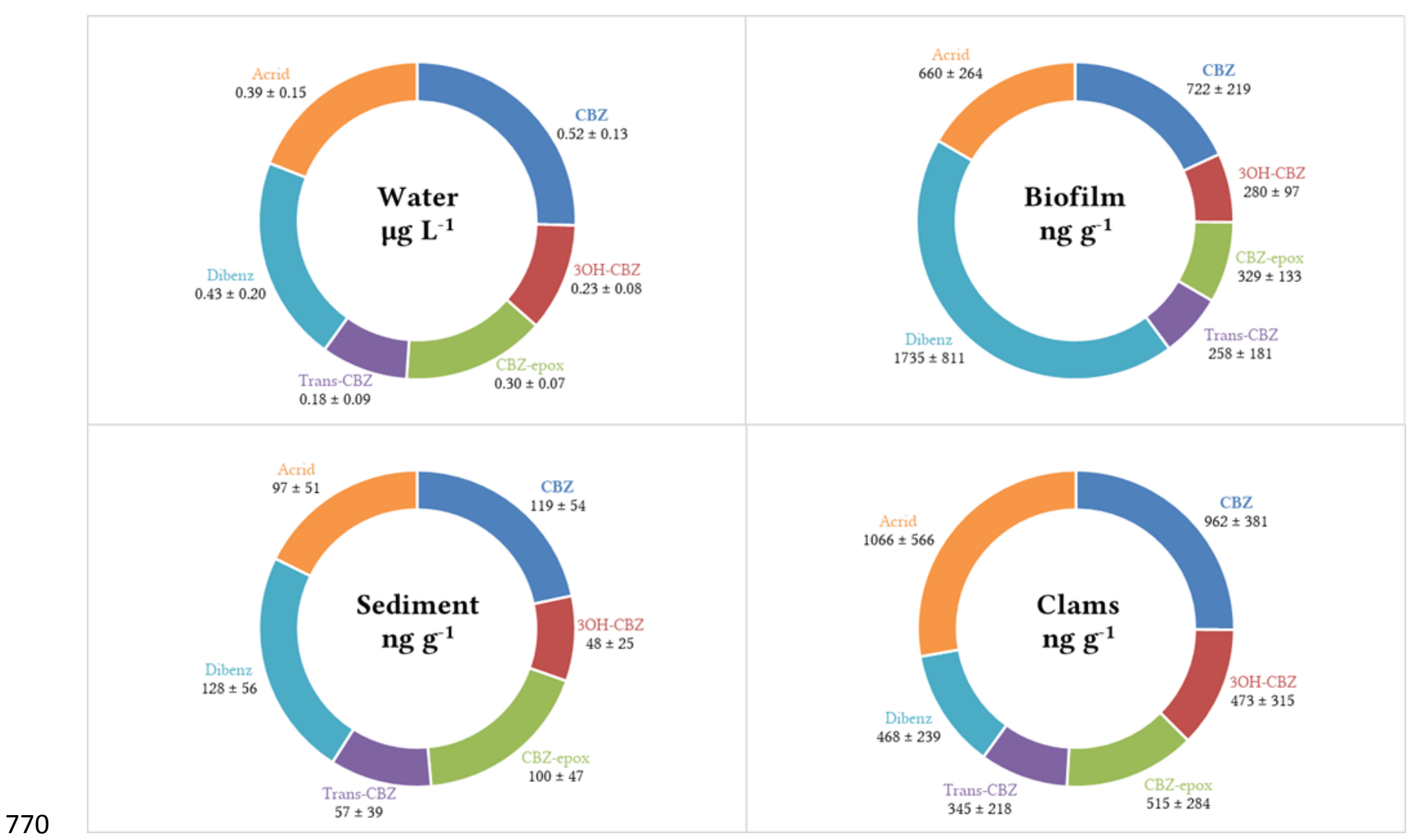


773 Figure 4: Ecotoxicity of targeted compounds and mixtures with respect to 774 Pseudokirchneriella subcapitata, Daphnia magna and Pimephales promelas. The values 775 were calculated using the QSAR Toolbox trend analysis approach. The lowest toxicity 776 endpoints are highlighted in red, and the highest in green, indicating the most and the 777 least toxic product from each studied family towards each species. Ecotoxicities of 778 individual compounds were used to estimate mixture ecotoxicities by trend analysis, 779 considering independent modes of actions and molar fractions observed from the 780 average concentrations measured in the studied waters.

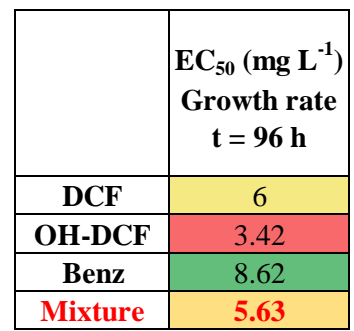

\begin{tabular}{|c|c|}
\hline CBZ & 10.4 \\
\hline 3OH-CBZ & 28.7 \\
\hline CBZ-epox & 107 \\
\hline Trans-CBZ & 707 \\
\hline Dibenz & 5.29 \\
\hline Acrid & 278 \\
\hline Mixture & $\mathbf{3 7}$ \\
\hline
\end{tabular}

\begin{tabular}{|c|c|}
\hline & $\begin{array}{c}\mathbf{L C}_{\mathbf{5 0}}\left(\mathbf{m g ~ L}^{\mathbf{- 1}}\right) \\
\text { Mortality } \\
\mathbf{t}=\mathbf{4 8} \mathbf{~ h}\end{array}$ \\
\hline DCF & 80.1 \\
\hline OH-DCF & 2.3 \\
\hline Benz & $2.88 \mathrm{E}+15$ \\
\hline Mixture & $\mathbf{1 7 1 0 0 0 0}$ \\
\hline
\end{tabular}

\begin{tabular}{|c|c|}
\hline CBZ & 111 \\
\hline 3OH-CBZ & 35.4 \\
\hline CBZ-epox & 37.6 \\
\hline Trans-CBZ & 7110 \\
\hline Dibenz & 1.58 \\
\hline Acrid & 99.9 \\
\hline Mixture & $\mathbf{4 0 . 8}$ \\
\hline
\end{tabular}

\begin{tabular}{|c|c|}
\hline & $\begin{array}{c}\mathbf{L C}_{\mathbf{5 0}}\left(\mathbf{m g ~ L}^{\mathbf{- 1}}\right) \\
\text { Mortality } \\
\mathbf{t}=\mathbf{9 6} \mathbf{~ h}\end{array}$ \\
\hline DCF & 11.2 \\
\hline OH-DCF & 10.7 \\
\hline Benz & 2.71 \\
\hline Mixture & $\mathbf{6 . 6 7}$ \\
\hline
\end{tabular}

\begin{tabular}{|c|c|}
\hline CBZ & 37.3 \\
\hline 3OH-CBZ & 120 \\
\hline CBZ-epox & 52.1 \\
\hline Trans-CBZ & 206 \\
\hline Dibenz & 3.27 \\
\hline Acrid & 233 \\
\hline Mixture & $\mathbf{4 1 . 5}$ \\
\hline
\end{tabular}

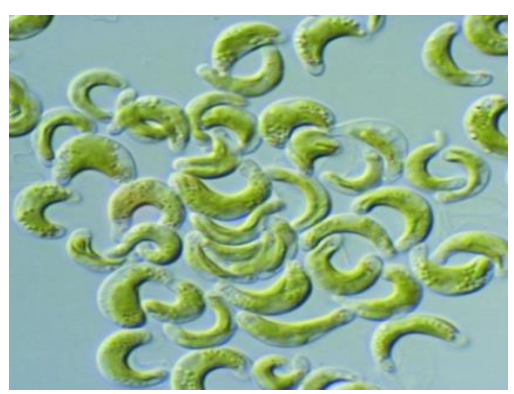

\begin{tabular}{|c|c|}
\hline & $\begin{array}{c}\mathbf{E C}_{\mathbf{5 0}}\left(\mathbf{m g ~ L}^{\mathbf{- 1}}\right) \\
\text { Growth inhibition } \\
\mathbf{t}=\mathbf{7 2} \mathbf{~ h}\end{array}$ \\
\hline ATZ & 0.14 \\
\hline DEA & 1.96 \\
\hline DIA & 1.7 \\
\hline DEDIA & 22.8 \\
\hline OH-ATZ & 0.26 \\
\hline Aniline & 17 \\
\hline
\end{tabular}

Pseudokirchneriella subcapitata

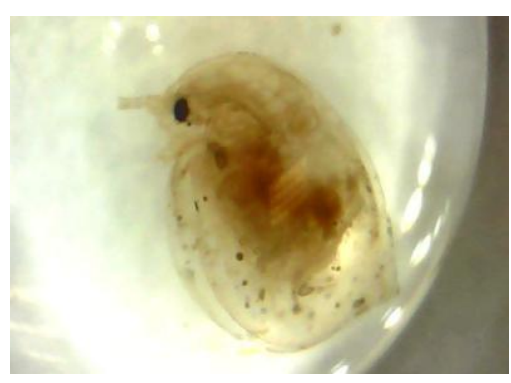

Daphnia magna

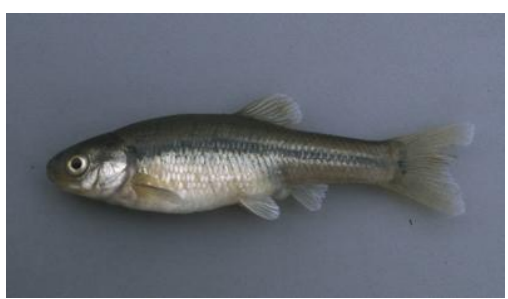

Pimephales promelas

\begin{tabular}{|c|c|}
\hline & $\begin{array}{c}\mathbf{L C}_{\mathbf{5 0}}\left(\mathbf{m g ~ L}^{\mathbf{- 1}}\right) \\
\text { Mortality } \\
\mathbf{t =} \mathbf{4 8} \mathbf{~ h}\end{array}$ \\
\hline ATZ & 6.9 \\
\hline DEA & 97.3 \\
\hline DIA & 152 \\
\hline DEDIA & 464 \\
\hline OH-ATZ & 3.41 \\
\hline Aniline & 0.08 \\
\hline
\end{tabular}

\begin{tabular}{|c|c|}
\hline & $\begin{array}{c}\mathbf{L C}_{\mathbf{5 0}}\left(\mathbf{m g ~ L}^{\mathbf{- 1}}\right) \\
\text { Mortality } \\
\mathbf{t = 9 6} \mathbf{~ h}\end{array}$ \\
\hline ATZ & 4.1 \\
\hline DEA & 15.6 \\
\hline DIA & 28 \\
\hline DEDIA & 120 \\
\hline OH-ATZ & 19.5 \\
\hline Aniline & 32 \\
\hline
\end{tabular}


782 Figure 5: Highlighting problematic compounds in the waters of the Vienne, the Clain 783 and the Thouet Rivers according to the associated risk (HQ) but also their level of 784 persistence (ultimate biodegradation half-life) (inspired by Mazellier et al. (2018))

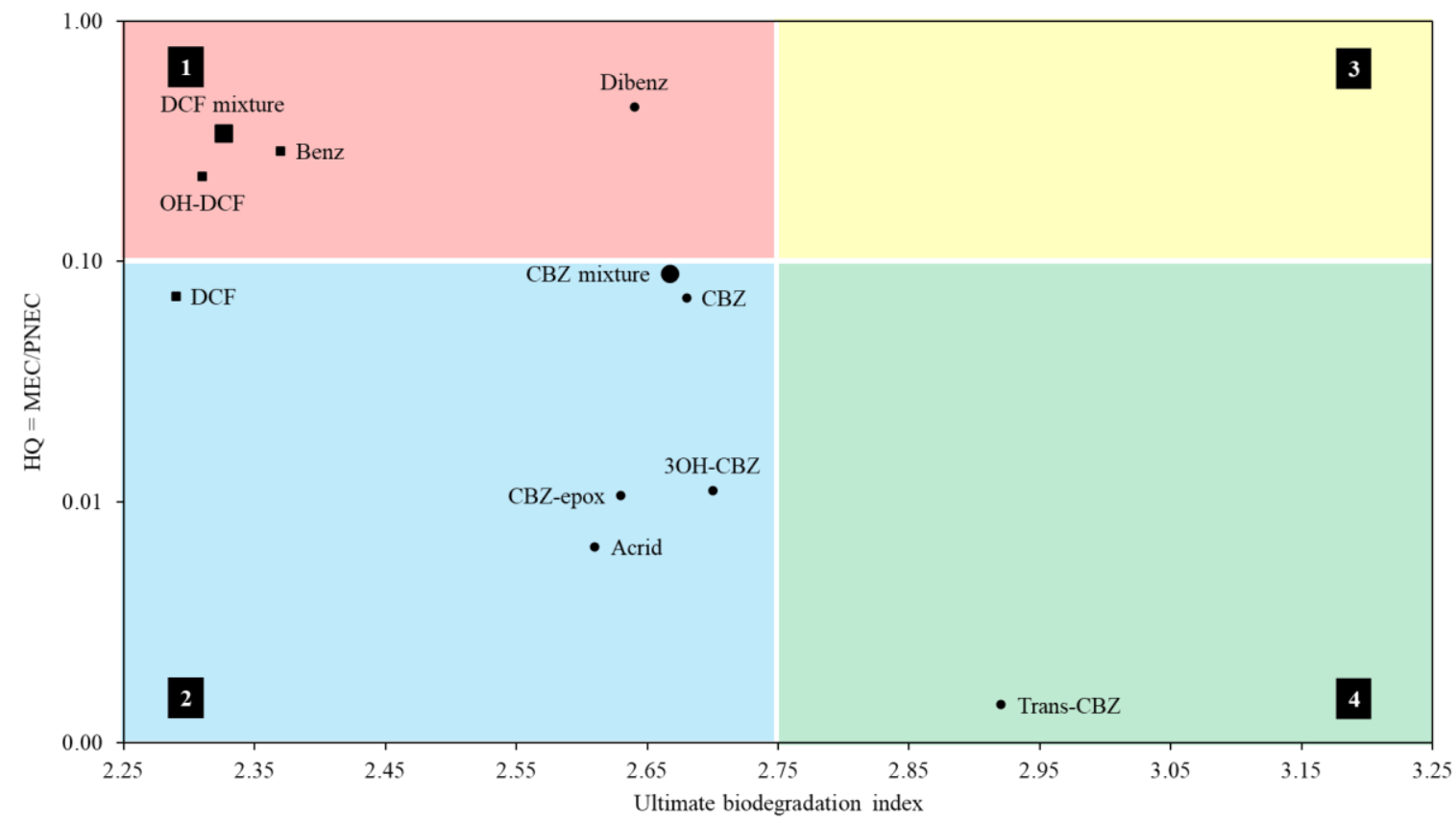


787 Figure 6: Highlighting problematic compounds in the sediments of the Vienne, the Clain 788 and the Thouet Rivers according to the associated risk (HQ) but also their level of 789 persistence (ultimate biodegradation half-life)

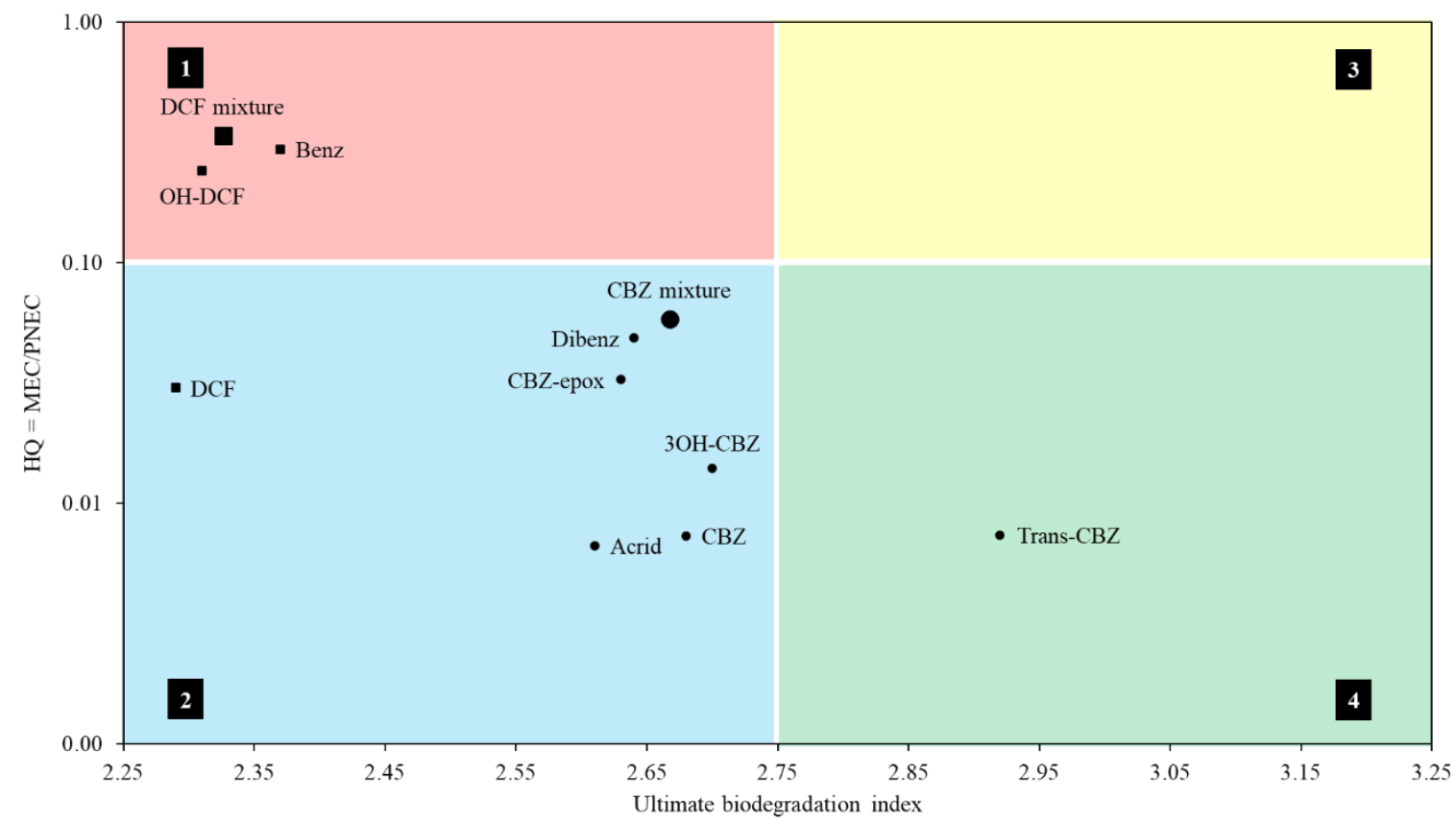

